\title{
The Pre-Deal Phase of Mergers and Acquisitions: A Review and Research Agenda
}

\author{
Welch, Xena ; Pavicevic, Stevo ; Keil, Thomas ; Laamanen, Tomi
}

\begin{abstract}
Despite the long-standing research interest in the pre-deal phase of mergers and acquisitions, many important questions remain unanswered. We review and synthesize the extensive but rather fragmented research on this topic area in the fields of management, finance, accounting, and economics. We organize our review according to six themes, that is, deal initiation, target selection, bidding and negotiation, valuation and financing, announcement, and closure, which represent the main categories of activities performed during the pre-deal phase. Our review shows that most of the existing research relies on a rather high-level, simplified, and static conception of the pre-deal phase. On the basis of our review, we put forward a research agenda that calls for a more granular examination of individual activities and decisions, a more comprehensive analysis of the interplay among the different actors involved in the pre-deal phase, a better understanding of the role of the temporal dynamics, and the extension of the theoretical base from variance-based to process-based theorizing.
\end{abstract}

DOI: https://doi.org/10.1177/0149206319886908

Posted at the Zurich Open Repository and Archive, University of Zurich

ZORA URL: https://doi.org/10.5167/uzh-192315

Journal Article

Accepted Version

Originally published at:

Welch, Xena; Pavicevic, Stevo; Keil, Thomas; Laamanen, Tomi (2020). The Pre-Deal Phase of Mergers and Acquisitions: A Review and Research Agenda. Journal of Management, 46(6):843-878.

DOI: https://doi.org/10.1177/0149206319886908 
THE PRE-DEAL PHASE OF MERGERS AND ACQUISITIONS:

A REVIEW AND RESEARCH AGENDA

\author{
Xena Welch* \\ Erasmus University Rotterdam
}

Stevo Pavićević

Frankfurt School of Finance and Management

Thomas Keil

University of Zurich

Tomi Laamanen

University of St. Gallen

Forthcoming in Journal of Management

*Corresponding author. The first two authors contributed equally. 


\begin{abstract}
Despite the long-standing research interest in the pre-deal phase of mergers and acquisitions, many important questions remain unanswered. We review and synthesize the extensive but rather fragmented research on this topic area in the fields of management, finance, accounting, and economics. We organize our review according to six themes, i.e., deal initiation, target selection, bidding and negotiation, valuation and financing, announcement, and closure, which represent the main categories of activities performed during the pre-deal phase. Our review shows that most of the existing research relies on a rather high level, simplified, and static conception of the pre-deal phase. Based on our review, we put forward a research agenda that calls for a more granular examination of individual activities and decisions, a more comprehensive analysis of the interplay among the different actors involved in the pre-deal phase, a better understanding of the role of the temporal dynamics, and the extension of the theoretical base from variance-based to process-based theorizing.
\end{abstract}

\title{
INTRODUCTION
}

Mergers and acquisitions (M\&A) represent important means for corporate change and growth.

Despite the lack of systematic evidence of shareholder value creation for the acquiring firm (e.g.,

Datta et al., 1992; King et al., 2004) and even claims of "wealth destruction on a massive scale" (Moeller et al., 2005), the total yearly value of worldwide M\&As has continued to grow. In the predeal phase of the M\&A process, which is defined as the period of a transaction that precedes the final closure of the deal, critical decisions are made regarding whether to engage in a deal, which company to buy, and how much to pay. Many of the challenges that surface later in the post- merger integration (PMI) process can be traced back to mistakes that occurred during the pre-deal phase (Haspeslagh \& Jemison, 1991). Therefore, further developing our understanding of the pre- deal phase of the M\&A process is important for both research and practice.

While prior reviews of the M\&A research exist, many have tended to approach the research area through a rather specific theoretical focus such as learning dynamics or executive compensation (e.g., Barkema \& Schijven, 2008; Bodolica \& Spraggon, 2009). In one of the most comprehensive reviews to date, Haleblian et al. (2009) surveyed research on the antecedents and 
consequences of M\&As. One conclusion of that review was a call for more research on the processes of M\&A implementation. Good progress has been made since then in the research on PMI processes, as shown in a recent review by Graebner et al. (2017). However, similar reviews with a focus on the pre-deal M\&A processes do not exist, although this body of research looks back on a long tradition and also has grown significantly over the past decade (see Figure 1). We address this gap by providing a comprehensive review of the state of the art and an assessment of the progress that has been made to date.

\section{[Insert Figure 1 about here]}

We organize our literature review according to six themes, which represent the main categories of activities and decisions of the pre-deal phase as identified in the prior research (e.g., Jemison \& Sitkin, 1986; Walsh, 1989). These categories include (1) initiation; (2) target selection; (3) bidding and negotiation; (4) valuation, financial terms and financing; (5) announcement; and (6) closure. The actions and decisions within and across these categories tend to be highly intertwined, involve different internal and external actors during different stages of the process, and often involve multiple recursive decision-making loops before the completion of the pre-deal phase is reached (Jemison \& Sitkin, 1986).

Based on our review, we identify four overarching issues that have held back research on the pre-deal phase. First, the prior research tends to collapse the pre-deal process into a single variable and focus only on completed deals. This approach results in a simplified depiction of the pre-deal phase that does not account for its multistage nature and overlooks the potential existence of multiple parallel processes that result in unrealized deals. Limiting analyses to only realized deals can result in a skewed or inaccurate portrayal of reality and an underestimation of the complexity of the decision-making processes that occur during the pre-deal phase. 
Second, research on the pre-deal phase tends to make relatively simplistic assumptions regarding the locus of decision-making and the stage-gated decision processes in which multiple actors play an important role. Prior studies often consider an aggregate viewpoint and treat the acquiring firm as a single and monolithic entity, or they selectively focus on a limited number of actors such as the CEOs of the merging firms or the boards of directors. Other relevant actors, such as the other members of the TMT, managers involved in dedicated corporate M\&A functions, advisors, and investors, have received minimal attention, limiting our understanding of the role of and interactions among the various internal and external actors during the pre-deal phase.

Third, the prior research has given limited attention to the different aspects of the temporal dynamics of the pre-deal process. Nearly no attention has been paid to the timing of various predeal decisions and actions and the consequences of such timing on the PMI process or other M\&A outcomes. Relatedly, the prior research has not addressed the inherently recursive nature of the predeal process in which parties move back and forth from one action or decision to another. M\&A processes can be placed on hold for different reasons and subsequently continued when the time is more opportune for the parties involved in the transaction. Additionally, other temporal characteristics of pre-deal actions and decisions, such as speed, rhythm, and synchronization with other corporate activities, have rarely been considered in the prior research.

Fourth, the theoretical perspectives that have been used have predominantly focused on variance theorizing at the expense of process theorizing. These issues originate from the theoretical emphasis of prior empirical research. As the pre-deal phase has typically only been considered a prelude to the more complex PMI phase in which process theorizing is more common, pre-deal researchers have tended to predominantly focus on theories explaining the quality of decisions (such as agency theory, information economics, and behavioral theory) instead of theories aiming 
to explain the temporal and evolutionary dynamics of the underlying processes.

Based on our review, we propose an agenda for future research investigating the pre-deal phase to address these gaps in the prior literature. We call for research that (a) moves from aggregate decisions to more granular processes, (b) shifts attention to a broader set of pre-deal actors and their complex interplay, (c) considers the temporality of M\&A processes by assuming a dynamic perspective, and (d) extends the theoretical base of the pre-deal research from variance- based to process-based theorizing. We highlight specific questions for future research and suggest theories and empirical approaches to help move the field forward.

\section{METHODOLOGY OF THE LITERATURE REVIEW}

To ensure comprehensive coverage of the relevant literature in our review, we analyzed the conceptual and empirical research examining the pre-deal phase of M\&As published in nineteen premier journals in the fields of management, finance, economics and accounting (see Table A1 in the Online Appendix for the list of journals) from their inception until the end of April 2019. To identify the relevant studies, we performed a search of the ISI database and identified articles with the keywords "M\&A", "acqui*”, "merg*", "deal", or "takeover". Based on abstracts, we eliminated articles that focused on either distant themes (e.g., "knowledge acquisition") or aspects that occur after M\&A closures such as the PMI process. To ensure consistency, all abstracts were independently read by two authors. To be included in our review, the articles had to investigate at least one aspect of the pre-deal phase of M\&A. The final pool of articles covered in this review contained 202 articles and spanned over four decades of research. Table A1 in the Online Appendix shows a breakdown of the research covered according to different disciplines and journals.

An acquiring firm's decision to initiate a deal is typically part of a broader consideration of strategic choices such as alliances or organic development. In our review, we did not consider 
these alternatives because a firm's governance mode choice has spawned an extensive stream of literature and separate reviews of this topic exist (e.g., Brouthers \& Hennart, 2007). Similarly, we excluded research related to divestitures (e.g., Brauer, 2006). We further excluded research related to post-M\&A executive turnover because such turnover is influenced by a broader set of considerations that are beyond the scope of the pre-deal phase, and this work has also been reviewed elsewhere (e.g., Bilgili et al., 2017). Finally, we excluded studies exploring expected or realized M\&A performance unless such studies considered at least one feature of the pre-deal phase as an antecedent to performance outcomes.

\section{LITERATURE REVIEW}

\section{Initiation}

The pre-deal phase typically begins with deal initiation, i.e., the decision to engage in an M\&A. Deal initiation can be triggered by either the acquiring or the target firm (e.g., Hunt, 1990) or outside actors such as investment banks or activist investors. The research on M\&A initiation can be logically grouped into four clusters: (1) studies on the strategic motives for initiating M\&As,

(2) studies on firm and industrylevel behavioral explanations underlying those motives, (3) studies on individual executive characteristics - predominantly CEOs' - and their inclination to initiate M\&As, and (4) studies on the role of governance and ownership in M\&A initiation.

M\&A motives. Early on Trautwein (1990) suggested that M\&As can be considered a rational choice, a process outcome, or the result of a macroeconomic phenomenon. From a rational choice perspective, M\&As are initiated to achieve a wide range of different objectives. Seth et al. (2000) and Seth (1990a, 1990b) suggest that rational motives aiming to benefit the acquirer's shareholders can be traced back to the M\&A strategy, which is determined by the overarching corporate strategy. Accordingly, M\&As are motivated by market power, economies of scale and 
scope, coinsurance benefits, or the diversification of risks. In addition to the more proactive motives, M\&As can also be defensive (Hopkins, 1991) or driven by private benefits as managers may acquire other firms to avoid losing private benefits if their firms are acquired (Gorton et al., 2009). While different studies have provided important insights into the motives of acquirers, seller or target-side motives have rarely been studied outside of the divestiture literature (e.g., Brauer, 2006; Feldman, 2013) even though in many cases, M\&As are initiated by sellers (e.g., Graebner \& Eisenhardt, 2004; Zeng et al., 2013). Moreover, these motives are often assumed only implicitly because they are difficult to capture in large scale statistical analyses (Rabier, 2017).

Behavioral explanations. M\&As can occur due to pressures for imitation (Baum et al., 2000; Haunschild, 1993; Haunschild \& Beckman, 1998; Yang \& Hyland, 2006). Fueled by regulatory or economic shocks (Harford, 2005; Schipper \& Thompson, 1983; Wan \& Yiu, 2009), these pressures can evolve into industry-spanning M\&A waves (Haleblian et al., 2012; Matsusaka, 1993) in which only first-movers tend to systematically exhibit performance gains (McNamara et al., 2008; Moeller et al., 2005). Additionally, social comparison in the form of social aspirations (Kim et al., 2015), competitor innovations (Kaul, 2012), or a decline in innovativeness compared to peers (Zhao, 2009) has been linked to the initiation of M\&As. A decline in reputation vis-à-vis a firm's peers has been found to increase deal activity as a means to recover reputation (Haleblian et al., 2017). Despite the progress in understanding the pressures for imitation, these studies provide limited insight into the internal decision-making processes that precede imitative M\&A behavior.

Momentum theory argues that organizational routines and cognitive decision-making patterns induce firms to repeat the same types of M\&A that they have conducted before (Amburgey \& Miner, 1992). This effect is pronounced if the acquisitions produce positive abnormal returns 
(Haleblian et al., 2006). Behavioral theory explanations of M\&As posit that attainment discrepancy can also lead to M\&As (Iyer \& Miller, 2008; Kim et al., 2015; Kuusela et al., 2017). Although the research on the behavioral dynamics of M\&As provides important insight into M\&A initiation, the extent to which different actors exhibit these tendencies and how the different behavioral tendencies are alleviated or magnified in different organizational settings remain unknown. Moreover, M\&A behavior is typically examined using datasets comprising primarily of completed deals. This can result in a sampling bias that may lead to misleading conclusions regarding M\&A behavior as the externally observable behavior may conflate the company's intended actions with the actions that the company is able to realize in practice.

Executive characteristics. A large body of work has examined how individual decision makers at the corporate apex shape M\&A initiation. In this body of work, the actor who has received the most research attention is the acquiring company's CEO. Target CEOs, in contrast, have been studied to a much more limited extent (Jenter \& Lewellen, 2015). In particular, the personalities and entrenchment of acquiring firms' CEOs have been long-standing themes in the M\&A literature (Roll, 1986) and continue to attract significant research attention. Based on upper echelons theory, several CEO characteristics have been linked to M\&A likelihood. The empirical findings indicate that CEOs who are young and male (Huang \& Kisgen, 2013; Levi et al., 2010; Yim, 2013), nonRepublican (Elnahas \& Kim, 2017), overconfident (Billett \& Qian, 2008; Hayward \& Hambrick, 1997; Malmendier \& Tate, 2008; Malmendier \& Tate, 2015), narcissistic (Chatterjee \& Hambrick, 2007; Zhu \& Chen, 2015), and extraverted (Malhotra et al., 2017) or have high promotion focus (Gamache et al., 2015) are more likely to initiate M\&As because they are confident in their ability to deliver high M\&A performance.

Shedding light on the role of entrenchment and self-serving behaviors, the research shows 
that CEOs are also more likely to initiate M\&As if their peers win CEO awards (Shi et al., 2017b) or if they are compensated less than their peers (Seo et al., 2015). Similarly, CEOs have been found to engage more actively in M\&As when they are compensated in stock options (Lewellen et al., 1985; Sanders, 2001) or have high relative power vis-à-vis the board (Grinstein \& Hribar, 2004). In contrast, personal experiences, such as fatal disasters in CEOs' early life (Bernile et al., 2017) or the death of directors on the board, have been found to make CEOs more sensitive to risky choices and render them less likely to decide in favor of M\&As (Shi et al., 2017a).

A smaller stream of research has examined the role of the TMT in M\&A initiation. This work suggests that prior M\&A experience of TMT members is positively related to M\&A initiation (Nadolska \& Barkema, 2014). Other studies have examined the social standing of TMT members and concluded that social status allows TMT members to identify a larger number of M\&A opportunities (El-Khatib et al., 2015; Palmer \& Barber, 2001). Collectively, these studies indicate that CEOs are not shaping M\&A in a social vacuum and that the role of the TMT and other corporate-level decision makers would merit further attention. For instance, the roles of M\&A heads and the directors in charge of strategy or business development have still been studied to a very limited extent (Trichterborn et al., 2016) despite their importance in the identification of M\&A opportunities. Similarly, TMT members' personal characteristics and experiences, unlike those of CEOs, are rarely explored as antecedents to decisions and actions in the pre-deal phase.

Governance and ownership. A large portion of extant literature tends to view the members of the board as passive actors who monitor and control the executive management of the firm (Hayward \& Hambrick, 1997). However, there is an increasing recognition that outside directors can also be proactive actors in the pre-deal process. Haunschild (1993) found that the inclination to engage in M\&As increases when directors have interlocking relationships with other 
acquiring companies, indicating that directors may act as agents for corporate imitation. Other studies have linked director gender and compensation to M\&A initiation. For instance, the proportion of female directors has been found to be negatively associated with initiation as female directors seem to exert more active oversight in evaluating deal proposals than their male counterparts (Chen et al., 2016). In addition, stock and stock option pay for outside directors has been found to be related in an inverted U-shaped manner to a firm's M\&A rate (Deutsch et al., 2007).

A growing research stream has examined the impact of different forms of ownership on M\&A initiation. Family owners, for instance, are less likely to initiate deals (Miller et al., 2010), because they are more risk-averse and prefer stability to prevent disruption in the firm legacy (Feldman et al., 2016). State ownership has been argued to reduce M\&As that are purely motivated by market expansion (Greve \& Man Zhang, 2017). An overlap in institutional ownership between prospective M\&A partners has been found to make certain deals more attractive and, thus, also more likely to be initiated (Goranova et al., 2010). Overall, despite the abundance of studies, important gaps remain as this research has not explored the interplay of owners, members of the board, and executives as well as outside actors such as banks or activist investors in the decision- making processes associated with M\&A initiation.

\section{Target selection}

Target selection encompasses the identification and pre-screening of prospective targets. To identify target firms, acquirers may rely on market screening, creating internal lists of potential targets that may be adjusted and updated as a part of the ongoing M\&A strategy work (e.g., Salter \& Weinhold, 1981). Alternatively, acquirers may resort to their networks or external advisors for advice. After identification, acquirers typically begin compiling information about the potential 
target to preliminarily assess the quality of the target and its fit with the acquirer along several dimensions (e.g., Datta, 1991; Hernandez \& Shaver, 2019; Shelton, 1988).

Most of the research on target selection has adopted the acquirer perspective, although M\&As are often also initiated by target firms (Boone \& Mulherin, 2007). A large portion of this research builds on resource and capability-based views to examine the characteristics of attractive targets with the implicit assumption that acquirers can rationally assess the value of targets' resources. Building on information economics and learning theories, another set of studies explores the role of information asymmetry in target value assessment as well as various mechanisms that can reduce information asymmetry. Finally, a third set of studies has considered the contextual factors that can pose additional challenges for acquirers in target selection decisions.

Target firm attractiveness. Resource and capability-based rationales play an important role in examining which firms are selected as acquisition targets. This research has shown that firms with strong patent portfolios (Bena \& Li, 2014; Ransbotham \& Mitra, 2010), other R\&D related resources and capabilities (Heeley et al., 2006; Ruckman, 2005), slack (Davis \& Stout, 1992), and environmental capabilities (Berchicci et al., 2012) are attractive M\&A targets. When assessing the quality and fit of a prospective target, acquirers evaluate these characteristics vis-à- vis their own. As a consequence, the concept of fit, understood as firm characteristics that either supplement or complement each other, has been central in the research focusing on target selection (Datta, 1991; Shelton, 1988). Acquirers have been found to select targets that have resources, products and R\&D pipelines similar to their own (Schildt \& Laamanen, 2006; Yu et al., 2016), targets with complementary capabilities (Kaul \& Wu, 2016), targets with related human capital (Lee et al., 2018), targets with geographically overlapping operations (Chen et al., 2018; Ramos \& Shaver, 2013), and targets that produce network synergies (Hernandez \& Shaver, 2019). 
While the recent methodological advances in exogenous stratification and propensity score matching enable the approximation of the pool of alternative M\&A targets (e.g., Chakrabarti \& Mitchell, 2013; Rogan \& Sorenson, 2014), the current research tends to confound potential targets that have never been considered with those that were a part of an actual decision-making process. Furthermore, the main concern would seem to be with the avoidance of Type I errors (avoiding a bad deal) at the expense of Type II errors (ensuring that all good deals are made). As a consequence, we continue to have limited knowledge regarding how acquiring executives and directors influence the pool of potential targets, whether and when they interact with the directors or executives of targets during the preliminary screening stage, and how they shape the selection criteria (Nolop, 2007).

Information asymmetry and learning. Information asymmetry can complicate the assessment of a target's resources and capabilities due to acquirers' limited information about potential acquisition targets (e.g., Capron \& Shen, 2007). The extant research suggests that to reduce information asymmetries, acquirers have a higher likelihood of acquiring targets that are former alliance partners (Porrini, 2004; Zaheer et al., 2010), geographically proximate (Chakrabarti \& Mitchell, 2013), or connected through common clients (Rogan \& Sorenson, 2014), auditors (Cai et al., 2016; Dhaliwal et al., 2016), or social ties among managers and directors (Ishii \& Xuan, 2014; Rousseau \& Stroup, 2015; Stuart \& Yim, 2010).

The related research on signaling theory suggests that information asymmetries induce acquirers to use publicly available signals of target quality such as the prominence of their venture capital investors or underwriters (Ragozzino \& Blevins, 2016; Ragozzino \& Reuer, 2007) or investors' opinions of the target stock (Chatterjee et al., 2012). The challenges in evaluating targets stem not only from asymmetric information but also from the difficulty in information 
interpretation. For instance, similar ownership structures can help firms better understand one another and are, thus, more likely to merge (Bettinazzi et al., 2018).

Baum et al. (2000) suggest that experiential learning processes lead firms to select targets that are geographically and organizationally similar to their most recent targets whereas vicarious learning processes lead acquirers to favor targets that are similar to the M\&A targets of their peers. Target selection has also been argued to be influenced by managers observing other M\&As taking place in a related business domain (Ozmel et al., 2017) or by performance feedback (Kumar et al., 2015).

Although the gathering, interpretation, and analysis of information regarding prospective targets are among the primary roles of dedicated M\&A functions (Trichterborn et al., 2016), the prior research provides only limited evidence of how such functions at the corporate or business levels contribute to the quality of target selection processes.

Contextual factors. While examining the effects of national culture, Ahern et al. (2015) found that acquirers are less likely to select targets in culturally distant contexts due to the anticipated difficulties in integration and synergy realization. Economic nationalism has been shown to restrict the target choice of international acquirers when governments prefer targets to remain domestically owned rather than foreign-owned (Serdar Dinc \& Erel, 2013). Other factors related to the institutional context, such as the quality of accounting disclosure (Erel et al., 2012), the strength of anti-director rights (Maas et al., 2019), labor market regulations (Alimov, 2015), and the strictness of antitrust laws (Clougherty, 2005), have also been found to shape target selection. Examining these factors is important because they impose restrictions on the choice set of potential targets. Target selection is often portrayed as a rational and systematic process in which numerous candidates are considered before the eventual target is chosen. However, target choices 
may also emerge simply because other targets were not available. Given the focus of the prior research on realized deals, our understanding of such constraints remains limited.

\section{Bidding and negotiations}

After deciding to explore the possibility of a deal further, the pre-deal phase continues with a bidding and negotiation process. An acquirer may approach the target with an initial indicative, non-binding offer that provides the starting point of a range of further actions, such as negotiations and decisions concerning the deal terms and deal alternatives, which may culminate in an eventual bid. The private negotiation process concludes with an agreement regarding the key terms and conditions of a deal formalized in a shareholder purchase agreement (Bruner, 2004). The processes related to the acquisition of public and privately held firms differ quite significantly due to stock exchange regulations and the need for an acquirer to submit a public tender offer without any insider information that other shareholders do not have (DePamphilis, 2009).

Research examining bidding and negotiations can be divided into three broad streams. These streams focus on the competition among bidders and the commitment of the different parties in the negotiation process, negotiation tactics, and the role of hostility and trust during negotiations.

Competition and commitment. The prior research has explored the different implications of competition in the bidding process. To obtain the highest price, approximately half of the sellers tend to negotiate with multiple bidders (Boone \& Mulherin, 2007, 2009). The presence of competing bids has been found to influence the price paid for M\&A targets, and the existence of a "winners curse" (de Bodt et al., 2018; Giliberto \& Varaiya, 1989) is well-established. Therefore, bidders tend to prefer exclusivity and bilateral negotiations (Aktas et al., 2010). Managing multiple bidders is also quite resource-consuming, and sellers commonly narrow the process to the most potential buyer candidates. Moreover, better information accessibility about the target firm may 
increase the acquiring firm's confidence regarding the capabilities of the target, and the acquirer may thus be willing to bid higher (Marquardt \& Zur, 2015). Competition from other bidders has an impact on the speed and commitment of negotiations. Experimental evidence indicates that acquirers are more committed when multiple bidders are involved and the bidding process is public (Haunschild et al., 1994). These findings are related to a rich body of conceptual work that argues that escalating commitment to a target firm is fueled by managerial self-interest, overconfidence, and risk-propensity despite the existence of negative or unfavorable information (Duhaime \& Schwenk, 1985; Jemison \& Sitkin, 1986; Pablo et al., 1996; Parvinen \& Tikkanen, 2007). Not surprisingly, Aktas et al. (2016) found that negotiation processes tend to be particularly fast when CEOs display narcissistic personality traits. Although deals are frequently abandoned at this stage (Cullinan et al., 2004; Eccles et al., 1999), the (positive or negative) implications of the aborted deals and the subsequent actions of failed bidders have not received much attention in the prior research.

Negotiation tactics. Since the distribution of M\&A gains between the acquirer and the target depends on their relative bargaining power (Cuypers et al., 2016), a substantial body of work has examined which bargaining tactics would allow the acquirer and the seller to negotiate more effectively. When there is significant information asymmetry between prospective partners and the threat of competing bids, acquirers may use preemptive or toehold bidding (Betton et al., 2009; Fishman, 1988, 1989; Singh, 1998), lower their initial premium (Bertrand et al., 2016; Betton et al., 2014), counter offers with lower cash offers and extend the bargaining over longer periods (Coff, 1999), create time pressure to speed up the targets' decisions (Graebner \& Eisenhardt, 2004), or introduce specific contractual clauses such as contingent earnouts (Cain et al., 2011; Ragozzino \& Reuer, 2009; Reuer et al., 2004). 
Conversely, target firms can attempt to improve their bargaining position with the use of termination fees (Bonaime et al., 2018; Officer, 2003) and lockups (Burch, 2001; Che \& Lewis, 2007; Coff, 2003). Target firms can invite additional bidders to participate in the M\&A process, order negotiations with multiple interested bidders sequentially (Povel \& Singh, 2006), or simply propose to the shareholders the rejection of inadequate bids (Bates \& Becher, 2017). When bargaining, targets also make critical decisions internally such as decisions about CEO equity ownership to co-align the CEO incentives with those of the shareholders (Buchholtz \& Ribbens, 1994; Fich et al., 2011; Heitzman, 2011) or decisions related to different measures to fight against potential takeovers (Field \& Karpoff, 2002). While our knowledge of the different negotiation tactics is relatively good, we have rather limited insight into the roles of the different actors such as legal or financial advisors who are on the negotiation team on behalf of and with the transaction parties and the implications of different negotiation team compositions with regard to the use and effectiveness of these tactics.

Hostility and trust. The prior research has highlighted the polarizing impact of trust on bargaining and negotiation processes. Friendliness has been argued to enable an open debate and decision-making without time pressure (Hunt, 1990). Despite the significant media attention that hostile takeover attempts tend to induce (Schneider \& Dunbar, 1992), hostile and friendly deals have been generally found to be indistinguishable in economic terms (Aktas et al., 2010; Schwert, 2000). More recently, however, the research has also begun to pay increasing attention to the role of trust in M\&A negotiations. Qualitative research shows how inter-organizational trust develops over time and how mutual trust of the prospective partners influences the extent of cooperation during the unfolding negotiation process (Graebner, 2009; Lander \& Kooning, 2013). Acquirers may not fully trust sellers because of asymmetric information, and sellers may bluff about the 
presence of alternative buyers or impose artificial deadlines for decision-making (Coff, 1999; Graebner, 2009). Overall, trust can have both direct and indirect consequences on bargaining outcomes. For instance, when the parties trust each other, they may exert more effort in bargaining, which, in turn, may increase their focus on synergy gains from the deal (Vaara \& Tienari, 2011).

In contrast to the research investigating deal initiation and target selection, the research on the bidding and negotiations stage is more balanced in its treatment of the acquirer and target perspectives and tends to incorporate both perspectives. However, substantial gaps in our understanding of the negotiation and bidding processes also remain. Given the difficulties in accessing fine-grained data regarding these processes, most work tends to ignore the individual influences of executives and directors on M\&A-related actions and decisions or assumes the influence implicitly based on a person's role. Additionally, our knowledge regarding the interdependences among the activities performed during bidding and negotiation and the initiation, selection, and due diligence activities is relatively limited.

\section{Valuation, financial terms, and financing}

While the initial assessment of the target value is commonly performed before the negotiation phase when the acquirer considers whether a target is worth pursuing, valuation activities continue during due diligence and in parallel with negotiations to improve the accuracy of valuation (Bruner, 2004; Jovanovic \& Braguinsky, 2004). The research on this topic area can be divided into studies on valuation and due diligence processes and key financial decisions such as the acquisition premium, acquired stake, method of payment, and sources of financing. These decisions are interrelated and emerge from due diligence and valuation processes that include several decision makers and advisors representing internal specialists and external financial, legal and strategic advisors. They are also closely connected to negotiations described in the previous section, and 
can be seen as the main outcomes of the negotiation process. In addition, these decisions often also have a legal dimension that is beyond the scope of this literature review.

Valuation and due diligence of target firms. A number of studies have examined different methods to quantify expected synergies from a deal (Gupta \& Gerchak, 2002; Kroll \& Caples, 1987). Another line of research had drawn upon signaling theory and suggests that acquirers may rely on various signals to determine the quality of targets such as relationships with prominent investment banks, venture capitalists, and alliance partners (Liu, 2011; Reuer et al., 2012). Human capital explanations have also been proposed, highlighting that industry and investment experience of managers and directors may lead to more accurate valuation (Custódio \& Metzger, 2013; Huang et al., 2014; Maitland \& Sammartino, 2015; Melone, 1994). Firms involved in M\&A also use the expertise of advisors and investment banks in estimating the target value (Kisgen \& Song, 2009; Rau, 2000; Sleptsov et al., 2013), although conflicts of interest have been argued to result in an upward-bias in valuation decisions (Golubov et al., 2012; Kesner et al., 1994; Lee, 2013). This effect can be reduced through rigorous monitoring by the acquirers' shareholders (Becht et al., 2016; Li et al., 2018). In contrast to the processes relating to valuation, there is surprisingly limited research about the due diligence process. While it is known that firms make substantial efforts and deploy internal teams complemented with specialized advisors (Harvey \& Lusch, 1995), it has been argued that due diligence efforts frequently fail to detect negative information about the target (Puranam et al., 2006). Thus, more research on the tools and processes of due diligence is needed.

M\&A premium. As the acquisition premium paid above the standalone value of an acquisition target is one of the most visible external manifestations of the height of a bid, an extensive body of research has examined the antecedents of M\&A premia. Several studies have 
found evidence of different types of cognitive biases in M\&A premium decisions. One such bias is the anchoring bias, which has been documented in different empirical studies (Baker et al., 2012; Malhotra et al., 2015). Premium decisions may also be influenced by polarized group decisionmaking in company boards (Zhu, 2013), directors' experiences with premium decisions in other firms (Beckman \& Haunschild, 2002; Haunschild, 1994), or connections between directors of merging firms (Cai \& Sevilir, 2012). Additionally, individual level considerations may influence the acquisition premium decision (Shleifer \& Vishny, 1988). For example, entrenched (Harford et al., 2012), overconfident (Hayward \& Hambrick, 1997; Malmendier \& Tate, 2008), narcissistic (Chatterjee \& Hambrick, 2011), and celebrity managers (Cho et al., 2016) have been found to pay higher premia. Additionally, incentives (Datta et al., 2001) and growth desperation (Kim et al., 2011) may lead to higher M\&A premia. However, although research has identified multiple sources of bias in M\&A premium decisions, the role of the different types of target shareholders, their heterogeneity, and their different views regarding the valuation of the firm have largely been overlooked even though the actual purpose of the M\&A premium is to convince shareholders to sell their shares. Furthermore, the degree to which financial advisors influence decisions related to M\&A premia and whether their judgment is influenced by different types of biases are unknown.

There is also research examining the acquisition premia from the perspective of the target. This research has found that the independence of the target board (Bange \& Mazzeo, 2004) and resistance by the target firm (Dimopoulos \& Sacchetto, 2014; Turk, 1992) can increase the premium. Furthermore, it has been suggested that target CEOs may be biased to accept a lower premium in exchange for a future position in the merged firm (Hartzell et al., 2004; Wulf, 2004) or special dealrelated bonuses (Cai \& Vijh, 2007; Fich et al., 2016; Hartzell et al., 2004). Interestingly, the research examining the target has paid rather limited attention to the impact of 
actors other than the board and the $\mathrm{CEO}$ in the premium setting process. In addition, this stream of research could benefit from a better understanding of how advisors influence M\&A premia.

Acquired stake. We define M\&A as the takeover of a majority stake, distinguishing M\&A from minority investments, alliances, and joint ventures. However, the size of the acquired stake may still vary. Decisions regarding the acquired stake are often discussed in detail in the practitioner literature (Bruner, 2004; DePamphilis, 2009); however, its antecedents have typically not been examined in depth outside of the international business research, which has focused on the effect of various country-level factors on the ownership share. Cuypers et al. (2015) find that acquirers acquire lower shares in foreign targets when the linguistic distance and differences in lingua franca proficiency are high. Malhotra and Gaur (2014) find a U-shaped relationship between geographic distance and equity stake. Chari and Chang (2009) find that the share of equity sought is influenced by the cost of the valuing foreign firm's assets, the difficulty in integrating foreign firm managers, the cost of separating desired assets from the rest of the foreign firm, and the cost of resource commitment under uncertainty. In cross-border deals, firms have also been found to use a sequential purchasing approach in which the deal is completed through staged equity purchases as opposed to a one-time transaction (Xu et al., 2010). Despite the importance of these considerations in crossborder deals, further research focusing on the tradeoffs associated with the percentage of shares acquired in domestic deals could enable us to better understand the different considerations related to the alignment of the incentives of the buyer and seller.

Method of payment. The choice of the payment method, that is, cash, stock or a combination of both, has been consistently found related to how the stock market reacts to the deal (King et al., 2004; Travlos, 1987). A payment by the acquiring firm's stock conveys the signal that the acquirer believes its stock to be overvalued, which tends to cause a negative stock market 
reaction to the choice of stock as the method of payment. However, the decision regarding the proportion of stock and cash to use as payment has also been argued to be related to information asymmetry considerations, the uncertainty regarding the value of the target and, on the seller's side, the uncertainty in the target firm's knowledge about the prospective acquirer (Eckbo et al., 2018). Moreover, this decision has been argued to be related to the general attractiveness of the prospective target (Malmendier et al., 2016), tax considerations (Brown \& Ryngaert, 1991), distribution of power among acquirer shareholders (Faccio \& Masulis, 2005), and the sensitivity of the bidder and target to market-related risk (Officer, 2004).

Deal financing. While deal financing has been a central consideration in the practitioner literature (Bruner, 2004; DePamphilis, 2009), scholarly interest in this topic area has (re)emerged only recently in finance research. Scholars have become interested in the sources of and constraints on the financing of M\&A. Examples of this research include the studies conducted by Gorbenko and Malenko (2017) and Burkart et al. (2014), who discuss how financial constraints and the external funding capacity may affect the bidding behavior of acquirers. Relatedly, Bates et al. (2018) suggest that earnout agreements in M\&A contracts provide an important source of financing for acquirers and that acquirers using earnouts tend to face tighter credit market conditions and use less debt and equity to fund M\&A. Given the importance of financing decisions, it is surprising that this topic area has not received more research attention.

\section{Announcement}

The deal announcement marks the end of the private pre-deal period conducted behind closed doors and the beginning of the public transaction period. The timing of the deal announcement differs in this respect between publicly and privately held acquisition targets, because in publicly held targets, the bid by an acquirer must be announced to the public often at a rather early stage. 
The literature related to deal announcements is relatively limited and may not fully reflect the importance of announcement-related actions and decisions. One of the areas that recent research has become interested in is related to the topic of impression management in the context of M\&A announcements. Another stream of research has focused on the effects of information leakage.

Impression management. Recent research has found that acquirers actively attempt to manage the impressions that their deals make since negative public perception and highly negative stock market reactions at the time of the M\&A announcement could jeopardize the endorsement of key stakeholders, threatening the likelihood of deal closure and the successful implementation of the deal (Lehn \& Zhao, 2006; Luo, 2005). Building upon expectancy violation theory, Graffin et al. (2016) found that acquirers released positive but unrelated information during a short time- window surrounding the M\&A announcement date to offset potential negative reactions to the deal by external stakeholders. Relatedly, Ahern and Sosyura (2014) analyzed stock-for-stock mergers and found that bidders published more press releases and employed more positive statements from the start of negotiations until the public acquisition announcement to keep their stock price up. Gamache et al. (2018) extended this research and argued that impression offsetting may serve as an ex ante signal of low CEO confidence in the value-creation potential of a deal. A firm may also foreshadow a deal by disclosing some information about a potential deal beforehand, thusallowing analysts to anticipate and make sense of upcoming M\&A announcements (Busenbark et al., 2017). Furthermore, scholars have found that acquirers are more likely to arrange conference calls to ensure that investors fully understand the motives and terms of the deal in deals financed by stock because the costs of a stock-based deal are directly tied to the value of the acquirer's stock (Kimbrough \& Louis, 2011). While the research on impression management in M\&A announcements seems to be growing, we have a limited knowledge regarding who in the acquiring 
firm decides on the use of different impression management tactics, whether target firms also use such tactics to manage the reaction of their own shareholders, and how long-lasting the effects of these tactics are.

Information leakage. The existence of speculative rumors and information leakages in the pre-deal phase is acknowledged as a way for a deal to become known to the public before the parties of the transaction make an announcement (Ahern \& Sosyura, 2014; Keown \& Pinkerton, 1981). The pre-deal process may be affected because such rumors could alter the negotiation dynamics or attract the attention of additional bidders. However, based on existing research, we have a limited understanding of the effects of information leakages on subsequent actions and decisions and how the different choices during the pre-deal phase, for example, regarding the size of the inner circle are related to the likelihood of rumors. Moreover, our understanding of the decision processes regarding the timing, content, and the effects of the announcements on the subsequent deal closure and the PMI processes remains relatively limited.

\section{Closure}

We consider closure the final stage of the pre-deal phase and define closure as the period between the M\&A announcement and completion or abandonment of the deal. At this stage, the parties often submit mandatory filings with securities regulators, seek approval by antitrust authorities, complete the negotiations regarding financing, hold a shareholder vote regarding the deal in the case of public targets and acquirers, sign the share purchase agreement, and prepare for the post- merger integration (Bruner, 2004; DePamphilis, 2009). Deal closure occurs when the parties have agreed on the deal terms, have obtained the necessary consents, sign the definitive share purchase agreement, and execute the mutual responsibilities defined in the contract. The deal can be still terminated at this stage if one of the parties decides to abandon the deal. The deal can also be 
blocked entirely or partially by antitrust authorities. While competition authorities commonly prevent firms from interacting too closely before a final approval is given, the involved companies can use the waiting time to prepare for the PMI stage.

The research on the closure of the pre-deal phase is scattered and has been primarily concerned with various factors that facilitate or hinder deal closure. One group of studies has examined how reducing uncertainty about target value facilitates deal closure and how various firmlevel factors may bias acquirers towards deal closure. In addition, a number of isolated efforts has been made to investigate how internal and external participants can shape the likelihood of deal closure and how this may affect the duration of the public takeover period.

Reducing deal uncertainty. During the public takeover stage, the acquirer and target continue to learn about each other (Martin \& Shalev, 2017). It has been suggested that target- related information is easier to access and interpret when the management of the target does not resist the deal (Walkling \& Long, 1984), as well as, when the buyer and target have related expertise (Coff, 2002). Building upon experiential learning theory, Muehlfeld et al. (2012) found that firms with experience from prior deals develop routines that make them better at completing deals. Contextual factors, such as formal and informal institutions (Dikova et al., 2010), business group affiliation (Kim \& Song, 2017), and the geographic distance between target and acquirer (Chakrabarti \& Mitchell, 2016), have also been found to influence deal closure. To overcome information asymmetry concerns and guard against residual uncertainty, acquirers can hire advisors (Boeh, 2011) or use contractual mechanisms such as termination fees (Bates \& Lemmon, 2003) and material adverse clauses (Denis \& Macias, 2013). Interestingly, M\&A contracts have received relatively limited attention in the management research compared to the related research in finance (e.g., Bates \& Lemmon, 2003) and the research on alliances (e.g., Reuer \& Ariño, 2007). 
It is important to note that forcing the deal to a closure is not always the best solution and that the pressure to close may contribute to non-optimal outcome. Relatedly, Zhao (2009) found that in high-tech industries, acquirers had less pressure to close a deal if they did not depend on acquisitions as external sources of innovation. Finally, status theory suggests that when prospective M\&A partners have status differences, the deal motivation and expected behaviors are clearer and the likelihood of deal completion is higher (Shen et al., 2014).

Effects of various participants. Acquiring CEOs who are younger are argued to be more dominance-seeking and have been found to exhibit a higher likelihood of withdrawing from a deal than CEOs who are older (Levi et al., 2010). Withdrawal from a deal following a negative market reaction to the deal announcement has been seen an indicator of the unobservable characteristics of a CEO (Jacobsen, 2014). Boards can incentivize negotiating CEOs with stock option awards to facilitate deal closure under favorable terms (Fich et al., 2011). Owners can also influence the timing and/or likelihood of completion. For example, state-owned acquirers (Li et al., 2017) or acquirers with large blockholders (Chen et al., 2019) have been found to take more time to close a deal. Furthermore, activist investors may attempt to delay deal closure through public campaigns (Jiang et al., 2018) or by encouraging managerial resistance (Boyson et al., 2017) to improve the terms of the deal. Interestingly, this research has not paid much attention to psychological explanations, such as the escalation of commitment or bandwagons effects, which can also be expected to play an important role in the likelihood of deal closure (e.g., Haunschild et al., 1994).

The presence of external participants in the pre-deal process can influence deal closure in multiple ways. Financial analysts have been found to play an important role in increasing or decreasing the likelihood of M\&A closure with their recommendations (Becher et al.,2015). Legal advisors are typically involved in public takeover processes and can have a major impact on the 
likelihood that an agreement is reached on favorable terms for both parties and the time that it takes to close a deal (Krishnan \& Masulis, 2013; Westbrock et al., 2019). The level and tone of media attention to the proposed transaction can also shape managers' decisions on whether to complete or abandon a deal (Liu \& McConnell, 2013).

The interactions between the acquiring firms and all affected competition authorities (in large mergers usually from a number of different countries and regions) and the role that these negotiations play in deal closure continue to represent major research gaps. The lack of deeper level internal data has prevented the development of more specific insights regarding the decisions, activities and overall workload associated with regulatory compliance, decisions and preparations regarding the divestitures needed to satisfy the conditions of antitrust authorities, and preintegration planning approaches. Finally, an important limitation of the prior research is that studies investigating deal closure have primarily examined M\&A attempts by publicly listed companies based on publicly available data.

\section{SYNTHESIS AND FUTURE RESEARCH AGENDA}

\section{Synthesis of the research gaps}

Based on our review of the extensive body of research on the pre-deal phase of M\&A, Table 1 synthesizes the topic areas and theories that have gained most scholarly attention in the extant research and highlights the most important gaps. While the research has made substantial progress since the review conducted by Haleblian et al. (2009), our review revealed that the extent of progress varied in different areas (see Figure 1). In particular, the research using M\&A initiation as a context for studying executive characteristics grew significantly in the last decade. The research on decisions and actions pertaining to target selection, deal announcement and closure, which barely existed a decade ago, have also begun gaining increasing interest. In the domain of 
bidding and negotiations, the research has gradually shifted towards micro-foundational factors that shape M\&A processes.

Table 1 provides a systematic comparison of the individual gaps. Reflecting back to the early call for research on M\&A processes (Jemison \& Sitkin, 1986), we identify four overarching issues that would seem to represent the root causes of current gaps and individually and in combination have hindered research progress. These issues are related to the rather high-level, treatment of the multitude of activities and decisions in the pre-deal stage, insufficient understanding of the roles and presence of the different actors and their interactions with each other, insufficient attention to the temporal dynamics of the different activities and decisions during the pre-deal phase, and the predominant emphasis of the empirical research on variance theorizing at the expense of process theorizing. We will next elaborate on these four issues before outlining the research agenda that we propose for future research on the pre-deal phase.

[Insert Table 1 around here]

Coarse-grained activities and processes. Prior research has attempted to capture the different stages of the pre-deal process through simplification and the use of a relatively limited number of high-level variables. This has resulted to an incomplete view of the pre-deal phase and its distinct activities and decisions. In particular, it has resulted into a limited attention to certain pre-deal activities, such as target screening or due diligence processes that represent a major proportion of the work performed by management in the pre-deal phase. To enhance our understanding of these activities, a more detailed examination of the processes and associated activities and decisions in the pre-deal phase would be needed. Disentangling the pre-deal phase into more granular micro-level processes, decisions, and activities could enhance our understanding of why some firms overpay or some deals derail during the subsequent PMI phase. 
Insufficient understanding of the multiple actors and their interactions. There is a tendency in the extant research to build on simplified assumptions about the locus of decisionmaking by casting firms as unitary actors or selectively focusing on individual actors who hold formal decision-making authority. However, the multitude of actors who influence decision- making or make deal-related decisions in different parts of the pre-deal phase are often not considered, as suggested in Table 1. Although prior work has emphasized the contested nature of M\&A decisions and interactions among the numerous boundedly rational actors who infuse their dispositions, preferences, and biases into the process, the role of many of these actors and especially their mutual interactions have not been systematically examined. However, understanding these roles and social interactions is highly important for deepening our knowledge of how decision-making practices in the pre-deal phase could be improved. For example, the status, relationships, or power distance among the various actors involved in the pre-deal processes could play a significant role in the quality of the pre-deal M\&A decision-making.

Lack of attention to the temporal dynamics. Prior research has not paid much attention to the temporal dynamics of the pre-deal phase, such as the timing and duration of different activities, and it has only rarely examined how pre-deal processes are affected by or synchronized with other firm activities. The pre-deal phase is subject to numerous interruptions, restarts, time pressures, and recursive decision dynamics across the stages, which can induce a myriad of behavioral and organizational responses. Furthermore, the activities occurring during the pre-deal stage may temporally coincide with other critical incidents related to either the acquiring or target firm, causing different actors to reschedule, delay, or speed up processes. Therefore, the timing of decisions and the duration, pace, and rhythm of the individual stages are crucial features of the pre-deal phase. However, we lack a dynamic view of the pre-deal stage that embraces the temporal 
embeddedness and dynamics of the pre-deal phase that could eventually affect deal completion, contractual terms, PMI-related activities, and deal outcomes.

Focus on variance theorizing at the expense of process theories. Underlying the three above observations is the historical reliance of the empirical research on variance theorizing over process theorizing (Mohr, 1982). The prior empirical research has examined the process based on the impact of independent variables on discrete outcomes such as the likelihood of deal initiation, the magnitude of the premium or the likelihood of deal completion. Less attention has been paid to "how and why things emerge, develop, grow, or terminate over time" (Langley et al., 2013: 1), although the conceptual work has long emphasized that the incidents that occur during the pre- deal process often have repercussions in the subsequent stages of the process and ultimately affect M\&A performance (Jemison \& Sitkin, 1986). Extending the theoretical foundations of the empirical research with process theories could enhance our understanding of how the different decisions and activities occurring during the pre-deal phase intertwine and unfold over time.

\section{Research agenda}

By reflecting upon these observations of the different gaps and their underlying root causes, we propose a research agenda that is organized into four research themes. In addition, Table A2 in the Online Appendix highlights questions for future research.

Research theme 1: From aggregate decisions to granular processes. Assuming that M\&A decisions are made instantaneously is too simplistic given that some M\&A transactions are years in the making. To gain a more accurate view of the pre-deal phase, we urge future research to (a) better disentangle the different actions and decisions occurring during the pre-deal phase that have usually been collapsed into a single variable, (b) pay more attention to neglected actions and decisions during the pre-deal phase, and (c) examine the interdependencies between the actions 
and decisions occurring during the pre-deal phase. To achieve these goals, we encourage scholars to collect more fine-grained datasets related to intermediary actions and decisions to develop a more detailed understanding of internal M\&A-related processes and practices.

To disentangle actions and decisions, it is important to study both completed and abandoned deals. Only a small proportion of deals evaluated by acquirers are ultimately realized. According to our interviews with M\&A heads, the ratio of initiated to closed deals can range from 10 to 1 to over 100 to 1 . From this perspective, the current pre-deal research has only studied the tip of the iceberg by focusing on completed deals. The omission of abandoned deals not only impedes our understanding of causation (Durand \& Vaara, 2009) but also neglects numerous interesting research opportunities because "long before an organization experiences many of the outcomes of a typical decision, it experiences a variety of collateral consequences associated with the making of the decision and its implementation" (March et al., 1991: 2). The analysis of abandoned deals could enhance our understanding of organizational learning and, given the significant amount of time and cognitive effort consumed by non-realized deals, our understanding of the activity load associated with M\&As (Castellaneta \& Zollo, 2014). Methodologically, developing a better understanding of the role of abandoned deals may require the collection of primary data through surveys and interviews and, when possible, an analysis of the internal archives related to M\&A opportunities evaluated by firms. In particular, serial acquirers often maintain detailed archives of their internal evaluation processes, which could be ideal for research purposes.

In addition, we recommend that future research pay more attention to the actions in which firms engage when anticipating and preparing for future deals. For instance, while it is known that firms sometimes foreshadow their M\&A plans to proactively position themselves as "acquirers of 
choice" (Chatterjee, 2009), we encourage researchers to also study the target mapping and screening processes that precede selection. Interesting research opportunities exist in this respect. For example, target identification can occur outside-in such that potential targets are suggested by advisors or initiated by the seller. It can, however, also occur inside-out through a proactive data collection process. Our knowledge of the comparative performance implications of such approaches in the identification of potential targets is limited. Many acquirers have corporate M\&A departments that invest significant effort in "deal sourcing". The rigor of such processes may have implications for the pre-deal phase of the M\&A and the quality of the transactions completed. Even simple survey-based indicators, such as the time spent on target identification or the identification mode (outside-in or inside-out) of initiated and completed transactions, could help advance our understanding of the target identification process.

Due diligence represents a pre-deal activity with a rich set of future research opportunities. Our review revealed that most current insight into due diligence processes is primarily based on practitioner-oriented research (e.g., Reed-Lajoux \& Elson, 2010). We lack even a basic understanding of how the different characteristics of due diligence, such as its length, pace, or coverage, affect the subsequent pre-deal process and M\&A outcomes. Scholars could, for example, build on theories of procedural rationality to investigate how the comprehensiveness of due diligence affects synergy estimates or M\&A premiums (Fredrickson, 1984). Similarly, future research could build on the work examining heuristics to examine due diligence as companies tend to develop heuristics to quickly assess target firms (e.g., Maitland \& Sammartino, 2015). Additional opportunities also exist on the theoretical front. For instance, the decision-making literature could be integrated with the bargaining literature to better understand how the decision- making speed during due diligence affects bargaining power. Given the secretive nature and the 
limited publicly available information regarding the due diligence process, conducting research focusing on due diligence may require closer collaboration with active acquirers and M\&A advisors similar to the research conducted by corporate governance scholars (e.g., Tuggle et al., 2010).

Further research could also be required to examine the independencies across the pre-deal process stages. Scholars should investigate how firms that anticipate the purchase or sale of a firm prepare for deal making activities. Preparatory activities can have a significant influence on all stages of the pre-deal process. For example, researchers could examine how contextual factors, such as the type of company and its counterpart (e.g., family ownership, culture, social context), influence the extent of pre-deal information gathering, bargaining strategies, and the nature of due diligence (cf. Jang et al., 2018).

Research theme 2: From individual actors to multiple actors and their interactions. To gain a more accurate understanding of the pre-deal phase, it is necessary to carefully dissect the locus of actions and decisions and extend beyond the simplistic assumption of the firm as a unitary actor or of the CEO or board of directors as the sole decision makers. Future studies should

(a) more explicitly depict the actors who influence the pre-deal phase and their discretion and authority to make decisions, (b) consider a wider range of actors and (c) examine the interactions among different actors.

Our review of the extant literature revealed that there is scarcity of research on the encounters of various internal and external actors during the M\&A pre-deal phase and their influence, authority and relative discretion. For example, the research investigating CEOs has often assumed a high degree of CEO discretion in pre-deal decisions. However, CEOs greatly differ not only in their latitude of action (Hambrick \& Finkelstein, 1987) but also in the extent to which they 
are involved in pre-deal processes (Heitzman, 2011). Governance research has often assigned the ultimate authority of approving or preventing M\&A deals to the board of directors; however, special M\&A committees may also play this role in some firms (Boone \& Mulherin, 2017).

We need a better understanding of when and to whom the boards of merging firms delegate authority to lead the pre-deal process. Who has the discretion to intervene with potentially flawed M\&A decisions, and when? In what capacity do members of TMTs or divisional managers become involved in the pre-deal process? What are the implications of these choices for the activities and decisions occurring during the pre-deal process and its outcomes? Researchers should explicitly explore these differences in the roles of the different actors as not considering these differences may limit the generalizability of the findings and even result in misleading results. The recent work in finance conducted by Graham et al. (2015) regarding the delegation of authority in M\&A decisions is a good example of how survey data can help address these questions.

Numerous actors involved during the pre-deal phase have received rather limited, if any, attention in the extant literature. We still have a limited understanding of how the management teams of specific units, such as divisions, board committees, and negotiation and due diligence teams in both the acquiring and target firms, influence the pre-deal process. While these groups do not always have formal decision authority, they can play an important role in identifying and evaluating prospective targets, and they may also have their own agenda. Heterogeneity in the nature and involvement of these groups during the pre-deal process may also explain the heterogeneity in M\&A outcomes. Socio-psychological theories of groups (e.g., Gladstein, 1984; McGrath, 1991) can provide a promising avenue for advancing the pre-deal research on this front. Relatedly, there has been a growing interest in the effects of top executives other than CEOs on strategic decisions (e.g., Menz \& Scheef, 2014). Yet, other than anecdotal evidence, relatively 
limited research has focused on the involvement and impact of these executives during the pre- deal phase. This may be partially due to data-related challenges in capturing the characteristics of these executives, their psychological profiles, responsibilities, and social interactions with one another. While this limitation can be overcome by collecting primary data, it is often difficult to perform such research on a larger scale. Despite some skepticism (Liu et al., 2018), there have been some important recent advancements on this front in capturing executive characteristicsusing secondary data, which could help pave the way for future research investigating the role of a broader group of top-level executives in the pre-deal phase (e.g., Shi et al., 2019).

While it is known that financial advisors are involved in pre-deal activities and charge significant fees for their services (e.g., Golubov et al., 2012), the research focusing on the activities through which they add value during the pre-deal process is quite limited. To better understand the role of advisors, more research focusing on their role in pre-deal activities and decisions is needed. Our understanding of the role of advisors could also be further improved by analyzing the characteristics of the individuals working for these advisors through dedicated databases, such as MergerMarket, that also track individuals (see Chatain \& Meyer-Doyle, 2017).

To address the interactions among the different actors, a broader set of theories seems warranted. Theories related to power distribution, social cohesion, and the diffusion of responsibilities in groups (e.g., Greer et al., 2017; Mullen \& Copper, 1994) can be used to study how the interplay between the CEO and other members of the TMT or the deal negotiation team influence decisions and actions. Theoretical approaches in the domain of dynamic interactionism (e.g., Reynolds et al., 2010) could be applied to explore how dyadic or polyadic interactions among the directors, CEOs, and other executives of the merging firms affect the pre-deal process and its outcomes. Theories of counterfactual thinking (e.g., Kahneman \& Miller, 1986) could enable us 
to better understand how interactions between external and internal actors may counter sociopsychological biases in M\&A decisions (e.g., Malhotra et al., 2015). Finally, the research focusing on the interactions among the different actors may also require novel empirical approaches that have not been previously applied in the research investigating the pre-deal phase such as interaction models that consider the dyadic and multiway social interaction among individuals (Back \& Kenny, 2010).

Research theme 3: From static to dynamic perspectives. Pre-deal actions and decisions do not occur in a vacuum. These activities are temporally embedded, may coincide with other critical events (e.g., other strategic initiatives) and are influenced by corporate schedules and deadlines (e.g., quarterly and yearly reporting). Therefore, we call for studies that more explicitly incorporate time into the pre-deal research (e.g., Ancona et al., 2001). Specifically, future research should investigate (a) the temporal embeddedness and timing of various pre-deal decisions and actions; (b) the temporal characteristics of pre-deal activities, such as duration, pace and frequency; and (c) the dynamics related to the recursive nature of pre-deal processes and activities.

Although the pre-deal phase often overlaps with a flurry of other strategic initiatives, the temporal embeddedness of M\&A processes remains generally poorly understood. The timing of different parallel initiatives may affect the attention that various actors can allocate to the focal deal (Ocasio, 1997). When multiple deal-making processes occur in parallel, actors can experience high levels of activity load (Castellaneta \& Zollo, 2014); even in well-defined M\&A programs, the quality of evaluation processes and deal outcomes may suffer (Laamanen \& Keil, 2008). Therefore, future research should consider the implications of the temporal embeddedness and synchronization of pre-deal activities for different M\&A outcomes.

The timing of different pre-deal activities also represents a more general under-researched 
area with many open questions. For instance, what are the implications of deliberate delays by targets during the negotiation process? A related question concerns the extent to which various actors can exercise control over different pre-deal activities. For example, M\&A teams that have previously worked together may have developed the ability to keep the timing of certain deal- related decisions and actions under their control (Gersick, 1989). However, external factors may influence the timing of the different pre-deal process stages or specific pre-deal decisions.

M\&As are frequently negotiated under time pressure. For example, when an acquirer makes an offer, the offer has a limited time for an acceptance or rejection decision by the target. In public takeover bids, the board of the acquiring firm must comment regarding the bid to the shareholders within a few days after receiving the bid. Takeover auctions are even more strictly driven by tight deadlines imposed by the target firm and the sell-side investment advisors. Overall, time and timing are critical considerations that could require a more systematic investigation in the pre-deal research. The literatures related to decision making under time constraints (e.g., Kocher \& Sutter, 2006), temporal group cognition (e.g., Mohammed \& Nadkarni, 2011), or intertemporal choice (e.g., Loewenstein, 1988) could provide useful theoretical starting points for developing predictions for this type of empirical research. To better empirically capture the timing of decisions and actions, future researchers could also use event history and sequence analyses.

Research is also required to determine whether shorter or longer pre-deal processes are more conducive for M\&A performance. The question of the speed of integration has been debated in PMI research (e.g., Homburg \& Bucerius, 2006); however, the speed of decision-making during the predeal phase has not received similar attention. This question is not only practically relevant but also theoretically intriguing given the plausible theoretical arguments in both directions. On the one hand, long processes are frequently reflections of divergent opinions between the merging 
parties or internal political tensions, which, in turn, could induce wide-spread frustration, conflict, and eventually value leakage. On the other hand, experimental studies suggest that pressure for fast decision-making is negativelyrelated to decision quality, giving rise to escalating commitment and due diligence failure (Haunschild et al., 1994; Puranam et al., 2006).

Pre-deal activities and decisions are interdependent and therefore frequently subject to reiterations and recursions. In particular, due diligence, valuation, and bidding and negotiations should be studied as an intertwined, iterative process whereby newly surfaced information during due diligence frequently requires adjustments in the assumptions that underlie the acquirer's and target's valuations and the revisiting of requested concessions during the bargaining process (Haspeslagh \& Jemison, 1991). Similarly, whether and to what extent public reactions following the announcement trigger the reassessment of the initial plans or even re-negotiation of the deal terms are unknown. The termination of already announced deals may have significant repercussions for potential targets as it may cause significant internal turmoil (Mantere et al., 2012) before the re-starting of negotiations with a new potential buyer or initiating an auction process. The study conducted by Vaara and Monin (2010) is an insightful example of how such research can be conducted. Recent negotiations research also provides an example for M\&A scholars of how to capture the recursive nature of bargaining processes (Jang et al., 2018).

Another important area upon which researchers and practitioners have speculated, but that has not yet been empirically examined, is related to the relationship between the temporal dimensions of the pre-deal process and the nature of PMI. Future research should explore how the duration of specific pre-deal stages, such as due diligence, influences the speed and duration of merger integration. Similarly, it could be important to explore how efforts PMI planning that already occur early in the pre-deal phase affect the subsequent integration process. 
Finally, research is needed to address the implication of interruptions and delays in the predeal process on M\&A outcomes. Interruptions may originate internally, such as from unexpected CEO departures or organizational problems, and externally, such as from the appearance of additional bidders or sellers, changes in the markets, or deal-related information leakage. These interruptions can be studied from a temporal perspective by asking questions, such as how the length of interruptions and the resulting delays affect the dynamics and outcomes of the pre-deal process, or building upon social psychology to examine the reactions of the individuals and groups involved in the deal-making process to such interruptions (Clary \& Tesser, 1983).

Research theme 4: From variance-based to process-based theories and methods. While the PMI research has shifted its focus over time to more processual theories following the initial call by Jemison and Sitkin (1986) to pay more attention to processes, the empirical research on the predeal decision-making process has been slower to follow suit. We call for an increased emphasis in the empirical research on process theories and methods that are better suited to conceptualize the pre-deal process as "a sequence of individual and collective events, actions, and activities unfolding over time in context" (Pettigrew, 1997: 337). A better understanding of the processual dynamics of the pre-deal stage is highly important because the decisions made during the pre-deal stage can have major consequences not only on the performance of a specific deal but also on the longer-term value creation for both the acquirer's and target's shareholders.

Theorizing on the process will allow us to address many of the research questions we have highlighted for which theoretical progress has been slow due to the extensive reliance on variancebased theorizing. For instance, it is well-established that M\&As emerge as a part of the corporate resource allocation process (Haspeslagh \& Jemison, 1991), which is an iterative and often political process that is influenced by cognitive biases and procedural path-dependence (Sengul et al., 
2019). M\&A decision-making is influenced by championing, issue selling, and the build-up of coalitions among divisional management, M\&A specialists, the TMT and the board of directors (Haspeslagh \& Jemison, 1991), which align dynamically over time. M\&A decision-making can also be regarded as a sensemaking process whereby the strategic vision and perceived viability of a deal shifts with each new piece of information that emerges (Haspeslagh \& Jemison, 1991). We thus call for studies to complement the current empirical research that mainly focuses on antecedent-outcome relationships with a more processual view that emphasizes process dynamics. What we frequently conceptualize as "outcomes" are often artificial staging points amid longer- term processes, and they should be analyzed and understood as such (Langley, 2007). A more in- depth return to the roots of the process research that showed that M\&A process dynamics can be conceptualized as fine-grained causal chains may be warranted (Jemison \& Sitkin, 1986).

Process theorizing may involve a range of theoretical lenses and include theories related to evolution, routines, learning, behavior, cognition, attention, sensemaking, and power (Van de Ven, 1992). While these theories differ in their focus and assumptions, they share the common focus of developing causal explanations for a phenomenon through processes consisting of temporally ordered events, activities, and choices rather than antecedent and outcome correlations (e.g., Langley, 1999). Our call to employ more processual theories resonates well with the recent developments in the strategy process and practice research and the call for the adoption of a "process ontology" in the study of what firms do (e.g., Burgelman et al., 2018). To theorize about processes, we must also revisit the methods used in the pre-deal research to enable us to develop and test process-based predictions. Therefore, methods, such as quantitative sequence analysis (e.g., Shi \& Prescott, 2011), longitudinal and comparative qualitative approaches (e.g., Graebner \& Eisenhardt, 2004) and critical discourse analyses (e.g., Vaara \& Monin, 2010), could be useful. 


\section{CONCLUSION}

Motivated by the growing interest in the pre-deal phase of the M\&A process, this review synthesizes findings from the research in management and related fields that investigated the pre- deal phase. Based on our review, we propose a future research agenda that encourages researchers to embark on a more granular investigation of the processes, actors, and temporality of the pre- deal phase and complement the predominant variance-based theorizing with process theories. We hope that such research will help us advance the frontiers of knowledge regarding the pre-phase and its consequences for a range of M\&A outcomes.

\section{REFERENCES}

Ahern, K. R., Daminelli, D., \& Fracassi, C. 2015. Lost in translation? The effect of cultural values on mergers around the world. Journal of Financial Economics, 117: 165-189.

Ahern, K. R., \& Sosyura, D. 2014. Who writes the news? Corporate press releases during merger negotiations. Journal of Finance, 69: 241-291.

Aktas, N., De Bodt, E., Bollaert, H., \& Roll, R. 2016. CEO narcissism and the takeover process: From private initiation to deal completion. Journal of Financial and Quantitative Analysis, 51: 113-137.

Aktas, N., De Bodt, E., \& Roll, R. 2010. Negotiations under the threat of an auction. Journal of Financial Economics, 98: 241-255.

Alimov, A. 2015. Labor market regulations and cross-border mergers and acquisitions. Journal of International Business Studies, 46: 984-1009.

Amburgey, T. L., \& Miner, A. S. 1992. Strategic momentum: The effects of repetitive, positional, and contextual momentum on merger activity. Strategic Management Journal, 13: 335-348.

Ancona, D. G., Goodman, P. S., Lawrence, B. S., \& Tushman, M. L. 2001. Time: A new research lens. Academy of Management Review, 26: 645-663.

Back, M. D., \& Kenny, D. A. 2010. The social relations model: How to understand dyadic processes. Social and Personality Psychology Compass, 4: 855-870.

Baker, M., Pan, X., \& Wurgler, J. 2012. The effect of reference point prices on mergers and acquisitions. Journal of Financial Economics, 106: 49-71.

Bange, M. M., \& Mazzeo, M. A. 2004. Board composition, board effectiveness, and the observed form of takeover bids. Review of Financial Studies, 17: 1185-1215.

Barkema, H. G., \& Schijven, M. 2008. How do firms learn to make acquisitions? A review of past research and an agenda for the future. Journal of Management, 34: 594-634.

Bates, T. W., \& Becher, D. A. 2017. Bid resistance by takeover targets: Managerial bargaining or bad faith? Journal of Financial and Quantitative Analysis, 52: 837-866. 
Bates, T. W., \& Lemmon, M. L. 2003. Breaking up is hard to do? An analysis of termination fee provisions and merger outcomes. Journal of Financial Economics, 69: 469-504.

Bates, T. W., Neyland, J. B., \& Wang, Y. Y. 2018. Financing acquisitions with earnouts. Journal of Accounting and Economics, 66: 374-395.

Baum, J. A., Li, S. X., \& Usher, J. M. 2000. Making the next move: How experiential and vicarious learning shape the locations of chains' acquisitions. Administrative Science Quarterly, 45: 766-801.

Becher, D. A., Cohn, J. B., \& Juergens, J. L. 2015. Do stock analysts influence merger completion? An examination of postmerger announcement recommendations. Management Science, 61: 2430-2448.

Becht, M., Polo, A., \& Rossi, S. 2016. Does mandatory shareholder voting prevent bad acquisitions? Review of Financial Studies, 29: 3035-3067.

Beckman, C. M., \& Haunschild, P. R. 2002. Network learning: The effects of partners' heterogeneity of experience on corporate acquisitions. Administrative Science Quarterly, 47: $92-124$.

Bena, J., \& Li, K. 2014. Corporate innovations and mergers and acquisitions. Journal of Finance, 69: 1923-1960.

Berchicci, L., Dowell, G., \& King, A. A. 2012. Environmental capabilities and corporate strategy: exploring acquisitions among US manufacturing firms. Strategic Management Journal, 33: 1053-1071.

Bernile, G., Bhagwat, V., \& Rau, P. R. 2017. What doesn't kill you will only make you more risk-loving: Early-life disasters and CEO behavior. Journal of Finance, 72: 167-206.

Bertrand, O., Betschinger, M. A., \& Settles, A. 2016. The relevance of political affinity for the initial acquisition premium in cross-border acquisitions. Strategic Management Journal, 37: 2071-2091.

Bettinazzi, E. L., Miller, D., Amore, M. D., \& Corbetta, G. 2018. Ownership similarity in mergers and acquisitions target selection. Strategic Organization, 11: 1-32.

Betton, S., Eckbo, B. E., Thompson, R., \& Thorburn, K. S. 2014. Merger negotiations with stock market feedback. Journal of Finance, 69: 1705-1745.

Betton, S., Eckbo, B. E., \& Thorburn, K. S. 2009. Merger negotiations and the toehold puzzle. Journal of Financial Economics, 91: 158-178.

Bilgili, T. V., Calderon, C. J., Allen, D. G., \& Kedia, B. L. 2017. Gone with the wind: A metaanalytic review of executive turnover, its antecedents, and postacquisition performance. Journal of Management, 43: 1966-1997.

Billett, M. T., \& Qian, Y. 2008. Are overconfident CEOs born or made? Evidence of selfattribution bias from frequent acquirers. Management Science, 54: 1037-1051.

Bodolica, V., \& Spraggon, M. 2009. Merger and acquisition transactions and executive compensation: A review of the empirical evidence. Academy of Management Annals, 3: 109181.

Boeh, K. K. 2011. Contracting costs and information asymmetry reduction in cross-border M\&A. Journal of Management Studies, 48: 568-590.

Bonaime, A., Gulen, H., \& Ion, M. 2018. Does policy uncertainty affect mergers and acquisitions? Journal of Financial Economics, 129: 531-558.

Boone, A. L., \& Mulherin, J. H. 2007. How are firms sold? Journal of Finance, 62: 847-875.

Boone, A. L., \& Mulherin, J. H. 2009. Is there one best way to sell a company? Auctions versus negotiations and controlled sales. Journal of Applied Corporate Finance, 21: 28-37. 
Boone, A. L., \& Mulherin, J. H. 2017. Who monitors the monitor? The use of special committees by target firms in corporate takeovers. Journal of Corporate Finance, 44: 388-404.

Boyson, N. M., Gantchev, N., \& Shivdasani, A. 2017. Activism mergers. Journal of Financial Economics, 126: 54-73.

Brauer, M. 2006. What have we acquired and what should we acquire in divestiture research? A review and research agenda. Journal of Management, 32: 751-785.

Brouthers, K. D., \& Hennart, J.-F. 2007. Boundaries of the firm: Insights from international entry mode research. Journal of Management, 33: 395-425.

Brown, D. T., \& Ryngaert, M. D. 1991. The mode of acquisition in takeovers: Taxes and asymmetric information. Journal of Finance, 46: 653-669.

Bruner, R. F. 2004. Applied mergers and acquisitions. New Jersey: John Wiley \& Sons.

Buchholtz, A. K., \& Ribbens, B. A. 1994. Role of chief executive officers in takeover resistance: Effects of CEO incentives and individual characteristics. Academy of Management Journal, 37: 554-579.

Burch, T. R. 2001. Locking out rival bidders: the use of lockup options in corporate mergers. Journal of Financial Economics, 60: 103-141.

Burgelman, R. A., Floyd, S. W., Laamanen, T., Mantere, S., Vaara, E., \& Whittington, R. 2018. Strategy processes and practices: Dialogues and intersections. Strategic Management Journal, 39: 531-558.

Burkart, M., Gromb, D., Mueller, H. M., \& Panunzi, F. 2014. Legal investor protection and takeovers. Journal of Finance, 69: 1129-1165.

Busenbark, J. R., Lange, D., \& Certo, S. T. 2017. Foreshadowing as impression management: Illuminating the path for security analysts. Strategic Management Journal, 38: 2486-2507.

Cai, J., \& Vijh, A. M. 2007. Incentive effects of stock and option holdings of target and acquirer CEOs. Journal of Finance, 62: 1891-1933.

Cai, Y., Kim, Y., Park, J. C., \& White, H. D. 2016. Common auditors in M\&A transactions. Journal of Accounting and Economics, 61: 77-99.

Cai, Y., \& Sevilir, M. 2012. Board connections and M\&A transactions. Journal of Financial Economics, 103: 327-349.

Cain, M. D., Denis, D. J., \& Denis, D. K. 2011. Earnouts: A study of financial contracting in acquisition agreements. Journal of Accounting and Economics, 51: 151-170.

Capron, L., \& Shen, J. C. 2007. Acquisitions of private vs. public firms: Private information, target selection, and acquirer returns. Strategic Management Journal, 28: 891-911.

Castellaneta, F., \& Zollo, M. 2014. The dimensions of experiential learning in the management of activity load. Organization Science, 26: 140-157.

Chakrabarti, A., \& Mitchell, W. 2013. The persistent effect of geographic distance in acquisition target selection. Organization Science, 24: 1805-1826.

Chakrabarti, A., \& Mitchell, W. 2016. The role of geographic distance in completing related acquisitions: Evidence from US chemical manufacturers. Strategic Management Journal, 37: 673-694.

Chari, M. D., \& Chang, K. 2009. Determinants of the share of equity sought in cross-border acquisitions. Journal of International Business Studies, 40: 1277-1297.

Chatain, O., \& Meyer-Doyle, P. 2017. Alleviating managerial dilemmas in human-capitalintensive firms through incentives: Evidence from M\&A legal advisors. Strategic Management Journal, 38: 232-254. 
Chatterjee, A., \& Hambrick, D. C. 2007. It's all about me: Narcissistic chief executive officers and their effects on company strategy and performance. Administrative Science Quarterly, 52: 351-386.

Chatterjee, A., \& Hambrick, D. C. 2011. Executive personality, capability cues, and risk taking: How narcissistic CEOs react to their successes and stumbles. Administrative Science Quarterly, 56: 202-237.

Chatterjee, S. 2009. The keys to successful acquisition programmes. Long Range Planning, 42: 137-163.

Chatterjee, S., John, K., \& Yan, A. 2012. Takeovers and divergence of investor opinion. Review of Financial Studies, 25: 227-277.

Che, Y. K., \& Lewis, T. R. 2007. The role of lockups in takeover contests. Rand Journal of Economics, 38: 648-669.

Chen, G., Crossland, C., \& Huang, S. 2016. Female board representation and corporate acquisition intensity. Strategic Management Journal, 37: 303-313.

Chen, V. T., Musacchio, A., \& Li, S. 2019. A principals-principals perspective of hybrid leviathans: Cross-border acquisitions by state-owned MNEs. Journal of Management, 45: 2751-2778.

Chen, Z., Kale, P., \& Hoskisson, R. 2018. Geographic overlap and acquisition pairing. Strategic Management Journal, 39: 329-355.

Cho, S. Y., Arthurs, J. D., Townsend, D. M., Miller, D. R., \& Barden, J. Q. 2016. Performance deviations and acquisition premiums: The impact of CEO celebrity on managerial risktaking. Strategic Management Journal, 37: 2677-2694.

Clary, E. G., \& Tesser, A. 1983. Reactions to unexpected events: The naive scientist and interpretive activity. Personality and Social Psychology Bulletin, 9: 609-620.

Clougherty, J. A. 2005. Antitrust holdup source, cross-national institutional variation, and corporate political strategy implications for domestic mergers in a global context. Strategic Management Journal, 26: 769-790.

Coff, R. 2003. Bidding wars over R\&D-intensive firms: Knowledge, opportunism, and the market for corporate control. Academy of Management Journal, 46: 74-85.

Coff, R. W. 1999. How buyers cope with uncertainty when acquiring firms in knowledgeintensive industries: Caveat emptor. Organization Science, 10: 144-161.

Coff, R. W. 2002. Human capital, shared expertise, and the likelihood of impasse in corporate acquisitions. Journal of Management, 28: 107-128.

Cullinan, G., Le Roux, J.-M., \& Weddigen, R.-M. 2004. When to walk away from a deal. Harvard Business Review, 82: 96-104, 141.

Custódio, C., \& Metzger, D. 2013. How do CEOs matter? The effect of industry expertise on acquisition returns. Review of Financial Studies, 26: 2008-2047.

Cuypers, I. R., Cuypers, Y., \& Martin, X. 2016. When the target may know better: Effects of experience and information asymmetries on value from mergers and acquisitions. Strategic Management Journal, 38: 609-625.

Cuypers, I. R., Ertug, G., \& Hennart, J.-F. 2015. The effects of linguistic distance and lingua franca proficiency on the stake taken by acquirers in cross-border acquisitions. Journal of International Business Studies, 46: 429-442.

Datta, D. K. 1991. Organizational fit and acquisition performance: Effects of post-acquisition integration. Strategic Management Journal, 12: 281-297. 
Datta, D. K., Pinches, G. E., \& Narayanan, V. 1992. Factors influencing wealth creation from mergers and acquisitions: A meta-analysis. Strategic Management Journal, 13: 67-84.

Datta, S., Iskandar-Datta, M., \& Raman, K. 2001. Executive compensation and corporate acquisition decisions. Journal of Finance, 56: 2299-2336.

Davis, G. F., \& Stout, S. K. 1992. Organization theory and the market for corporate control: A dynamic analysis of the characteristics of large takeover targets, 1980-1990. Administrative Science Quarterly, 37: 605-605.

de Bodt, E., Cousin, J.-G., \& Roll, R. 2018. Empirical evidence of overbidding in M\&A contests. Journal of Financial and Quantitative Analysis, 53: 1547-1579.

Denis, D. J., \& Macias, A. J. 2013. Material adverse change clauses and acquisition dynamics. Journal of Financial and Quantitative Analysis, 48: 819-847.

DePamphilis, D. 2009. Mergers, acquisitions, and other restructuring activities: An integrated approach to process, tools, cases, and solutions. Los Angeles: Academic Press.

Deutsch, Y., Keil, T., \& Laamanen, T. 2007. Decision making in acquisitions: The effect of outside directors' compensation on acquisition patterns. Journal of Management, 33: 30-56.

Dhaliwal, D. S., Lamoreaux, P. T., Litov, L. P., \& Neyland, J. B. 2016. Shared auditors in mergers and acquisitions. Journal of Accounting and Economics, 61: 49-76.

Dikova, D., Sahib, P. R., \& Van Witteloostuijn, A. 2010. Cross-border acquisition abandonment and completion: The effect of institutional differences and organizational learning in the international business service industry, 1981-2001. Journal of International Business Studies, 41: 223-245.

Dimopoulos, T., \& Sacchetto, S. 2014. Preemptive bidding, target resistance, and takeover premiums. Journal of Financial Economics, 114: 444-470.

Duhaime, I. M., \& Schwenk, C. R. 1985. Conjectures on cognitive simplification in acquisition and divestment decision making. Academy of Management Review, 10: 287-295.

Durand, R., \& Vaara, E. 2009. Causation, counterfactuals, and competitive advantage. Strategic Management Journal, 30: 1245-1264.

Eccles, R. G., Lanes, K. L., \& Wilson, T. C. 1999. Are you paying too much for that acquisition? Harvard Business Review, 77: 136-148.

Eckbo, B. E., Makaew, T., \& Thorburn, K. S. 2018. Are stock-financed takeovers opportunistic? Journal of Financial Economics, 128: 443-465.

El-Khatib, R., Fogel, K., \& Jandik, T. 2015. CEO network centrality and merger performance. Journal of Financial Economics, 116: 349-382.

Elnahas, A. M., \& Kim, D. 2017. CEO political ideology and mergers and acquisitions decisions. Journal of Corporate Finance, 45: 162-175.

Erel, I., Liao, R. C., \& Weisbach, M. S. 2012. Determinants of cross-border mergers and acquisitions. Journal of Finance, 67: 1045-1082.

Faccio, M., \& Masulis, R. W. 2005. The choice of payment method in European mergers and acquisitions. Journal of Finance, 60: 1345-1388.

Feldman, E. R. 2013. Legacy divestitures: Motives and implications. Organization Science, 25: 815-832.

Feldman, E. R., Amit, R., \& Villalonga, B. 2016. Corporate divestitures and family control. Strategic Management Journal, 37: 429-446.

Fich, E. M., Cai, J., \& Tran, A. L. 2011. Stock option grants to target CEOs during private merger negotiations. Journal of Financial Economics, 101: 413-430. 
Fich, E. M., Rice, E. M., \& Tran, A. L. 2016. Contractual revisions in compensation: Evidence from merger bonuses to target CEOs. Journal of Accounting and Economics, 61: 338-368.

Field, L. C., \& Karpoff, J. M. 2002. Takeover defenses of IPO firms. Journal of Finance, 57: 1857-1889.

Fishman, M. J. 1988. A theory of preemptive takeover bidding. Rand Journal of Economics, 19: 88-101.

Fishman, M. J. 1989. Preemptive bidding and the role of the medium of exchange in acquisitions. Journal of Finance, 44: 41-57.

Fredrickson, J. W. 1984. The comprehensiveness of strategic decision processes: Extension, observations, future directions. Academy of Management Journal, 27: 445-466.

Gamache, D., McNamara, G., Graffin, S., Kiley, J., Haleblian, J., \& Devers, C. 2018. Impression offsetting as an early warning signal of low CEO confidence in acquisitions. Academy of Management Journal, In-Press.

Gamache, D. L., McNamara, G., Mannor, M. J., \& Johnson, R. E. 2015. Motivated to acquire? The impact of CEO regulatory focus on firm acquisitions. Academy of Management Journal, 58: 1261-1282.

Gersick, C. J. 1989. Marking time: Predictable transitions in task groups. Academy of Management Journal, 32: 274-309.

Giliberto, S. M., \& Varaiya, N. P. 1989. The winner's curse and bidder competition in acquisitions: Evidence from failed bank auctions. Journal of Finance, 44: 59-75.

Gladstein, D. L. 1984. Groups in context: A model of task group effectiveness. Administrative Science Quarterly, 29: 499-517.

Golubov, A., Petmezas, D., \& Travlos, N. G. 2012. When it pays to pay your investment banker: New evidence on the role of financial advisors in M\&As. Journal of Finance, 67: 271-311.

Goranova, M., Dharwadkar, R., \& Brandes, P. 2010. Owners on both sides of the deal: mergers and acquisitions and overlapping institutional ownership. Strategic Management Journal, 31: 1114-1135.

Gorbenko, A. S., \& Malenko, A. 2017. The timing and method of payment in mergers when acquirers are financially constrained. Review of Financial Studies, 31: 3937-3978.

Gorton, G., Kahl, M., \& Rosen, R. J. 2009. Eat or be eaten: A theory of mergers and firm size. Journal of Finance, 64: 1291-1344.

Graebner, M. E. 2009. Caveat venditor: Trust asymmetries in acquisitions of entrepreneurial firms. Academy of Management Journal, 52: 435-472.

Graebner, M. E., \& Eisenhardt, K. M. 2004. The seller's side of the story: Acquisition as courtship and governance as syndicate in entrepreneurial firms. Administrative Science Quarterly, 49: 366-403.

Graebner, M. E., Heimeriks, K. H., Huy, Q. N., \& Vaara, E. 2017. The process of postmerger integration: A review and agenda for future research. Academy of Management Annals, 11: $1-32$.

Graffin, S., Haleblian, J., \& Kiley, J. 2016. Ready, AIM, acquire: Impression offsetting and acquisitions. Academy of Management Journal, 59: 232-252.

Graham, J. R., Harvey, C. R., \& Puri, M. 2015. Capital allocation and delegation of decisionmaking authority within firms. Journal of Financial Economics, 115: 449-470.

Greer, L. L., Van Bunderen, L., \& Yu, S. 2017. The dysfunctions of power in teams: A review and emergent conflict perspective. Research in Organizational Behavior, 37: 103-124. 
Greve, H. R., \& Man Zhang, C. 2017. Institutional logics and power sources: Merger and acquisition decisions. Academy of Management Journal, 60: 671-694.

Grinstein, Y., \& Hribar, P. 2004. CEO compensation and incentives: Evidence from M\&A bonuses. Journal of Financial Economics, 73: 119-143.

Gupta, D., \& Gerchak, Y. 2002. Quantifying operational synergies in a merger/acquisition. Management Science, 48: 517-533.

Haleblian, J., Devers, C. E., McNamara, G., Carpenter, M. A., \& Davison, R. B. 2009. Taking stock of what we know about mergers and acquisitions: A review and research agenda. Journal of Management, 35: 469-502.

Haleblian, J., McNamara, G., Kolev, K., \& Dykes, B. J. 2012. Exploring firm characteristics that differentiate leaders from followers in industry merger waves: A competitive dynamics perspective. Strategic Management Journal, 33: 1037-1052.

Haleblian, J. J., Kim, J.-Y. J., \& Rajagopalan, N. 2006. The influence of acquisition experience and performance on acquisition behavior: Evidence from the US commercial banking industry. Academy of Management Journal, 49: 357-370.

Haleblian, J. J., Pfarrer, M. D., \& Kiley, J. T. 2017. High-reputation firms and their differential acquisition behaviors. Strategic Management Journal, 38: 2237-2254.

Hambrick, D. C., \& Finkelstein, S. 1987. Managerial discretion: A bridge between polar views of organizational outcomes. Research in Organizational Behavior, 9: 369-406.

Harford, J. 2005. What drives merger waves? Journal of Financial Economics, 77: 529-560.

Harford, J., Humphery-Jenner, M., \& Powell, R. 2012. The sources of value destruction in acquisitions by entrenched managers. Journal of Financial Economics, 106: 247-261.

Hartzell, J. C., Ofek, E., \& Yermack, D. 2004. What's in it for me? CEOs whose firms are acquired. Review of Financial Studies, 17: 37-61.

Harvey, M. G., \& Lusch, R. F. 1995. Expanding the nature and scope of due diligence. Journal of Business Venturing, 10: 5-21.

Haspeslagh, P. C., \& Jemison, D. B. 1991. Managing acquisitions: Creating value through corporate renewal. New York: Free Press.

Haunschild, P. R. 1993. Interorganizational imitation: The impact of interlocks on corporate acquisition activity. Administrative Science Quarterly, 38: 564-592.

Haunschild, P. R. 1994. How much is that company worth? Interorganizational relationships, uncertainty, and acquisition premiums. Administrative Science Quarterly, 39: 391-411.

Haunschild, P. R., \& Beckman, C. M. 1998. When do interlocks matter?: Alternate sources of information and interlock influence. Administrative Science Quarterly, 43: 815-844.

Haunschild, P. R., Davis-Blake, A., \& Fichman, M. 1994. Managerial overcommitment in corporate acquisition processes. Organization Science, 5: 528-540.

Hayward, M. L., \& Hambrick, D. C. 1997. Explaining the premiums paid for large acquisitions: Evidence of CEO hubris. Administrative Science Quarterly, 42: 103-127.

Heeley, M. B., King, D. R., \& Covin, J. G. 2006. Effects of firm R\&D investment and environment on acquisition likelihood. Journal of Management Studies, 43: 1513-1535.

Heitzman, S. 2011. Equity grants to target CEOs during deal negotiations. Journal of Financial Economics, 102: 251-271.

Hernandez, E., \& Shaver, J. M. 2019. Network synergy. Administrative Science Quarterly, 64: 171-202. 
Homburg, C., \& Bucerius, M. 2006. Is speed of integration really a success factor of mergers and acquisitions? An analysis of the role of internal and external relatedness. Strategic Management Journal, 27: 347-367.

Hopkins, H. D. 1991. Acquisition and divestiture as a response to competitive position and market structure. Journal of Management Studies, 28: 665-677.

Huang, J., \& Kisgen, D. J. 2013. Gender and corporate finance: Are male executives overconfident relative to female executives? Journal of Financial Economics, 108: 822-839.

Huang, Q., Jiang, F., Lie, E., \& Yang, K. 2014. The role of investment banker directors in M\&A. Journal of Financial Economics, 112: 269-286.

Hunt, J. W. 1990. Changing pattern of acquisition behaviour in takeovers and the consequences for acquisition processes. Strategic Management Journal, 11: 69-77.

Ishii, J., \& Xuan, Y. 2014. Acquirer-target social ties and merger outcomes. Journal of Financial Economics, 112: 344-363.

Iyer, D. N., \& Miller, K. D. 2008. Performance feedback, slack, and the timing of acquisitions. Academy of Management Journal, 51: 808-822.

Jacobsen, S. 2014. The death of the deal: Are withdrawn acquisition deals informative of CEO quality? Journal of Financial Economics, 114: 54-83.

Jang, D., Elfenbein, H. A., \& Bottom, W. P. 2018. More than a phase: Form and features of a general theory of negotiation. Academy of Management Annals, 12: 318-356.

Jemison, D. B., \& Sitkin, S. B. 1986. Corporate acquisitions: A process perspective. Academy of Management Review, 11: 145-163.

Jenter, D., \& Lewellen, K. 2015. CEO preferences and acquisitions. Journal of Finance, 70: 2813-2852.

Jiang, W., Li, T., \& Mei, D. 2018. Influencing control: Jawboning in risk arbitrage. Journal of Finance, 73: 2635-2675.

Jovanovic, B., \& Braguinsky, S. 2004. Bidder discounts and target premia in takeovers. American Economic Review, 94: 46-56.

Kahneman, D., \& Miller, D. T. 1986. Norm theory: Comparing reality to its alternatives. Psychological Review, 93: 136.

Kaul, A. 2012. Technology and corporate scope: Firm and rival innovation as antecedents of corporate transactions. Strategic Management Journal, 33: 347-367.

Kaul, A., \& Wu, B. 2016. A capabilities-based perspective on target selection in acquisitions. Strategic Management Journal, 37.

Keown, A. J., \& Pinkerton, J. M. 1981. Merger announcements and insider trading activity: An empirical investigation. Journal of Finance, 36: 855-869.

Kesner, I. F., Shapiro, D. L., \& Sharma, A. 1994. Brokering mergers: An agency theory perspective on the role of representatives. Academy of Management Journal, 37: 703-721.

Kim, H., \& Song, J. 2017. Filling institutional voids in emerging economies: The impact of capital market development and business groups on M\&A deal abandonment. Journal of International Business Studies, 48: 308-323.

Kim, J.-Y., Finkelstein, S., \& Haleblian, J. 2015. All aspirations are not created equal: The differential effects of historical and social aspirations on acquisition behavior. Academy of Management Journal, 58: 1361-1388.

Kim, J. Y., Haleblian, J., \& Finkelstein, S. 2011. When firms are desperate to grow via acquisition: The effect of growth patterns and acquisition experience on acquisition premiums. Administrative Science Quarterly, 56: 26-60. 
Kimbrough, M. D., \& Louis, H. 2011. Voluntary disclosure to influence investor reactions to merger announcements: An examination of conference calls. Accounting Review, 86: 637667.

King, D. R., Dalton, D. R., Daily, C. M., \& Covin, J. G. 2004. Meta-analyses of post-acquisition performance: Indications of unidentified moderators. Strategic Management Journal, 25 : 187-200.

Kisgen, D. J., \& Song, W. 2009. Are fairness opinions fair? The case of mergers and acquisitions. Journal of Financial Economics, 91: 179-207.

Kocher, M. G., \& Sutter, M. 2006. Time is money: Time pressure, incentives, and the quality of decision-making. Journal of Economic Behavior \& Organization, 61: 375-392.

Krishnan, C., \& Masulis, R. W. 2013. Law firm expertise and merger and acquisition outcomes. Journal of Law and Economics, 56: 189-226.

Kroll, M., \& Caples, S. 1987. Managing acquisitions of strategic business units with the aid of the arbitrage pricing model. Academy of Management Review, 12: 676-685.

Kumar, M. V. S., Dixit, J., \& Francis, B. 2015. The impact of prior stock market reactions on risk taking in acquisitions. Strategic Management Journal, 36: 2111-2121.

Kuusela, P., Keil, T., \& Maula, M. 2017. Driven by aspirations, but in what direction? Performance shortfalls, slack resources, and resource-consuming vs. resource-freeing organizational change. Strategic Management Journal, 38: 1101-1120.

Laamanen, T., \& Keil, T. 2008. Performance of serial acquirers: Toward an acquisition program perspective. Strategic Management Journal, 29: 663-672.

Lander, M. W., \& Kooning, L. 2013. Boarding the aircraft: Trust development amongst negotiators of a complex merger. Journal of Management Studies, 50: 1-30.

Langley, A. 1999. Strategies for theorizing from process data. Academy of Management Review, 24: 691-710.

Langley, A. 2007. Process thinking in strategic organization. Strategic Organization, 5: 271-282.

Langley, A., Smallman, C., Tsoukas, H., \& Van de Ven, A. H. 2013. Process studies of change in organization and management: Unveiling temporality, activity, and flow. Academy of Management Journal, 56: 1-13.

Lee, J. J. 2013. Dancing with the enemy? Relational hazards and the contingent value of repeat exchanges in M\&A markets. Organization Science, 24: 1237-1256.

Lee, K. H., Mauer, D. C., \& Xu, E. Q. 2018. Human capital relatedness and mergers and acquisitions. Journal of Financial Economics, 129: 111-135.

Lehn, K. M., \& Zhao, M. X. 2006. CEO turnover after acquisitions: Are bad bidders fired ? Journal of Finance, 61: 1759-1811.

Levi, M., Li, K., \& Zhang, F. 2010. Deal or no deal: Hormones and the mergers and acquisitions game. Management Science, 56: 1462-1483.

Lewellen, W., Loderer, C., \& Rosenfeld, A. 1985. Merger decisions and executive stock ownership in acquiring firms. Journal of Accounting and Economics, 7: 209-231.

Li, J., Xia, J., \& Lin, Z. Y. 2017. Cross-Border Acquisitions by State-Owned Firms: How do Legitimacy Concerns Affect the Completion and Duration of their Acquisitions? Strategic Management Journal, 38: 1915-1934.

Li, K., Liu, T., \& Wu, J. 2018. Vote avoidance and shareholder voting in mergers and acquisitions. Review of Financial Studies, 31: 3176-3211.

Liu, B., \& McConnell, J. J. 2013. The role of the media in corporate governance: Do the media influence managers' capital allocation decisions? Journal of Financial Economics, 110: 1-17. 
Liu, D., Fisher, G., \& Chen, G. 2018. CEO attributes and firm performance: A sequential mediation process model Academy of Management Annals, 12: 789-816.

Liu, T. 2011. Takeover bidding with signaling incentives. Review of Financial Studies, 25: 522556.

Loewenstein, G. F. 1988. Frames of mind in intertemporal choice. Management Science, 34: 200-214.

Luo, Y. 2005. Do insiders learn from outsiders? Evidence from mergers and acquisitions. Journal of Finance, 60: 1951-1982.

Maas, A. J. J., Heugens, P., \& Reus, T. 2019. Viceroys or Emperors? An Institution-Based Perspective on Merger and Acquisition Prevalence and Shareholder Value. Journal of Management Studies, 56: 234-269.

Maitland, E., \& Sammartino, A. 2015. Decision making and uncertainty: The role of heuristics and experience in assessing a politically hazardous environment. Strategic Management Journal, 36: 1554-1578.

Malhotra, S., \& Gaur, A. S. 2014. Spatial geography and control in foreign acquisitions. Journal of International Business Studies, 45: 191-210.

Malhotra, S., Reus, T., Zhu, P., \& Roelofsen, E. 2017. The acquisitive nature of extraverted CEOs. Administrative Science Quarterly, 63: 370-408.

Malhotra, S., Zhu, P., \& Reus, T. H. 2015. Anchoring on the acquisition premium decisions of others. Strategic Management Journal, 36: 1866-1876.

Malmendier, U., Opp, M. M., \& Saidi, F. 2016. Target revaluation after failed takeover attempts: Cash versus stock. Journal of Financial Economics, 119: 92-106.

Malmendier, U., \& Tate, G. 2008. Who makes acquisitions? CEO overconfidence and the market's reaction. Journal of Financial Economics, 89: 20-43.

Malmendier, U., \& Tate, G. 2015. Behavioral CEOs: The role of managerial overconfidence. Journal of Economic Perspectives, 29: 37-60.

Mantere, S., Schildt, H. A., \& Sillince, J. A. 2012. Reversal of strategic change. Academy of Management Journal, 55: 172-196.

March, J. G., Sproull, L. S., \& Tamuz, M. 1991. Learning from samples of one or fewer. Organization Science, 2: 1-13.

Marquardt, C., \& Zur, E. 2015. The role of accounting quality in the M\&A market. Management Science, 61: 604-623.

Martin, X., \& Shalev, R. 2017. Target firm-specific information and acquisition efficiency. Management Science, 63: 672-690.

Matsusaka, J. G. 1993. Takeover motives during the conglomerate merger wave. Rand Journal of Economics, 24: 357-379.

McGrath, J. E. 1991. Time, interaction, and performance (TIP): A theory of groups. Small Group Research, 22: 147-174.

McNamara, G. M., Haleblian, J., \& Dykes, B. J. 2008. The performance implications of participating in an acquisition wave: Early mover advantages, bandwagon effects, and the moderating influence of industry characteristics and acquirer tactics. Academy of Management Journal, 51: 113-130.

Melone, N. P. 1994. Reasoning in the executive suite: The influence of role/experience-based expertise on decision processes of corporate executives. Organization Science, 5: 438-455.

Menz, M., \& Scheef, C. 2014. Chief strategy officers: Contingency analysis of their presence in top management teams. Strategic Management Journal, 35: 461-471. 
Miller, D., Le Breton-Miller, I., \& Lester, R. H. 2010. Family ownership and acquisition behavior in publicly-traded companies. Strategic Management Journal, 31: 201-223.

Moeller, S. B., Schlingemann, F. P., \& Stulz, R. M. 2005. Wealth destruction on a massive scale? A study of acquiring-firm returns in the recent merger wave. Journal of Finance, 60: 757-782.

Mohammed, S., \& Nadkarni, S. 2011. Temporal diversity and team performance: The moderating role of team temporal leadership. Academy of Management Journal, 54: 489-508.

Mohr, L. B. 1982. Explaining organizational behavior. San Francisco: Jossey-Bass.

Muehlfeld, K., Sahib, P. R., \& Van Witteloostuijn, A. 2012. A contextual theory of organizational learning from failures and successes: A study of acquisition completion in the global newspaper industry, 1981-2008. Strategic Management Journal, 33: 938-964.

Mullen, B., \& Copper, C. 1994. The relation between group cohesiveness and performance: An integration. Psychological Bulletin, 115: 210-227.

Nadolska, A., \& Barkema, H. G. 2014. Good learners: How top management teams affect the success and frequency of acquisitions. Strategic Management Journal, 35: 1483-1507.

Nolop, B. 2007. Rules to acquire by. Harvard Business Review, 85: 129-137.

Ocasio, W. 1997. Towards an attention-based view of the firm. Strategic Management Journal, 18: 187-206.

Officer, M. S. 2003. Termination fees in mergers and acquisitions. Journal of Financial Economics, 69: 431-467.

Officer, M. S. 2004. Collars and renegotiation in mergers and acquisitions. Journal of Finance, 59: 2719-2743.

Ozmel, U., Reuer, J. J., \& Wu, C. W. 2017. Interorganizational imitation and acquisitions of high-tech ventures. Strategic Management Journal, 38: 2647-2665.

Pablo, A. L., Sitkin, S. B., \& Jemison, D. B. 1996. Acquisition decision-making processes: The central role of risk. Journal of Management, 22: 723-746.

Palmer, D., \& Barber, B. M. 2001. Challengers, elites, and owning families: A social class theory of corporate acquisitions in the 1960s. Administrative Science Quarterly, 46: 87-120.

Parvinen, P., \& Tikkanen, H. 2007. Incentive asymmetries in the mergers and acquisitions process. Journal of Management Studies, 44: 759-787.

Pettigrew, A. M. 1997. What is a processual analysis? Scandinavian journal of management, 13: 337-348.

Porrini, P. 2004. Can a previous alliance between an acquirer and a target affect acquisition performance? Journal of Management, 30: 545-562.

Povel, P., \& Singh, R. 2006. Takeover contests with asymmetric bidders. Review of Financial Studies, 19: 1399-1431.

Puranam, P., Powell, B. C., \& Singh, H. 2006. Due diligence failure as a signal detection problem. Strategic Organization, 4: 319-348.

Rabier, M. R. 2017. Acquisition motives and the distribution of acquisition performance. Strategic Management Journal, 38: 2666-2681.

Ragozzino, R., \& Blevins, D. P. 2016. Venture-backed firms: How does venture capital involvement affect their likelihood of going public or being acquired? Entrepreneurship Theory and Practice, 40: 991-1016.

Ragozzino, R., \& Reuer, J. J. 2007. Initial public offerings and the acquisition of entrepreneurial firms. Strategic Organization, 5: 155-176. 
Ragozzino, R., \& Reuer, J. J. 2009. Contingent earnouts in acquisitions of privately held targets. Journal of Management, 35: 857-879.

Ramos, M. A., \& Shaver, J. M. 2013. When individual locations affect the choice of multilocation acquisition targets. Strategic Organization, 11: 125-155.

Ransbotham, S., \& Mitra, S. 2010. Target Age and the Acquisition of Innovation in HighTechnology Industries. Management Science, 56: 2076-2093.

Rau, P. R. 2000. Investment bank market share, contingent fee payments, and the performance of acquiring firms. Journal of Financial Economics, 56: 293-324.

Reed-Lajoux, A., \& Elson, C. 2010. The art of M\&A due diligence: Navigating critical steps \& uncovering crucial data (2nd ed.). New York: McGraw-Hill.

Reuer, J. J., \& Ariño, A. 2007. Strategic alliance contracts: Dimensions and determinants of contractual complexity. Strategic Management Journal, 28: 313-330.

Reuer, J. J., Shenkar, O., \& Ragozzino, R. 2004. Mitigating risk in international mergers and acquisitions: the role of contingent payouts. Journal of International Business Studies, 35: 19-32.

Reuer, J. J., Tong, T. W., \& Wu, C.-W. 2012. A signaling theory of acquisition premiums: Evidence from IPO targets. Academy of Management Journal, 55: 667-683.

Reynolds, K. J., Turner, J. C., Branscombe, N. R., Mavor, K. I., Bizumic, B., \& Subašić, E. 2010. Interactionism in personality and social psychology: An integrated approach to understanding the mind and behaviour. European Journal of Personality, 24: 458-482.

Rogan, M., \& Sorenson, O. 2014. Picking a (poor) partner: A relational perspective on acquisitions. Administrative Science Quarterly, 59: 301-329.

Roll, R. 1986. The hubris hypothesis of corporate takeovers. Journal of Business, 59: 197-216.

Rousseau, P. L., \& Stroup, C. 2015. Director histories and the pattern of acquisitions. Journal of Financial and Quantitative Analysis, 50: 671-698.

Ruckman, K. 2005. Technology sourcing through acquisitions: Evidence from the US drug industry. Journal of International Business Studies, 36: 89-103.

Salter, M. S., \& Weinhold, W. A. 1981. Choosing compatible acquisitions. Harvard Business Review, 59: 117-127.

Sanders, W. G. 2001. Behavioral responses of CEOs to stock ownership and stock option pay. Academy of Management Journal, 44: 477-492.

Schildt, H. A., \& Laamanen, T. 2006. Who buys whom: information environments and organizational boundary spanning through acquisitions. Strategic Organization, 4: 111-133.

Schipper, K., \& Thompson, R. 1983. The impact of merger-related regulations on the shareholders of acquiring firms. Journal of Accounting research, 21: 184-221.

Schneider, S. C., \& Dunbar, R. L. M. 1992. A psychoanalytic reading of hostile takeover events. Academy of Management Review, 17: 537-567.

Schwert, G. W. 2000. Hostility in takeovers: in the eyes of the beholder? Journal of Finance, 55: 2599-2640.

Sengul, M., Costa, A. A., \& Gimeno, J. 2019. The allocation of capital within firms. Academy of Management Annals, 13: 43-83.

Seo, J., Gamache, D. L., Devers, C. E., \& Carpenter, M. A. 2015. The role of CEO relative standing in acquisition behavior and CEO pay. Strategic Management Journal, 36: 18771894.

Serdar Dinc, I., \& Erel, I. 2013. Economic nationalism in mergers and acquisitions. Journal of Finance, 68: 2471-2514. 
Seth, A. 1990a. Sources of value creation in acquisitions: an empirical investigation. Strategic Management Journal, 11: 431-446.

Seth, A. 1990b. Value creation in acquisitions: A re-examination of performance issues. Strategic Management Journal, 11: 99-115.

Seth, A., Song, K. P., \& Pettit, R. 2000. Synergy, managerialism or hubris? An empirical examination of motives for foreign acquisitions of US firms. Journal of International Business Studies, 31: 387-405.

Shelton, L. M. 1988. Strategic business fits and corporate acquisition: Empirical evidence. Strategic Management Journal, 9: 279-287.

Shen, R., Tang, Y., \& Chen, G. L. 2014. When the role fits: How firm status differentials affect corporate takeovers. Strategic Management Journal, 35: 2012-2030.

Shi, W., Hoskisson, R. E., \& Zhang, Y. A. 2017a. Independent director death and CEO acquisitiveness: Build an empire or pursue a quiet life? Strategic Management Journal, 38: 780-792.

Shi, W., \& Prescott, J. E. 2011. Sequence patterns of firms' acquisition and alliance behaviour and their performance implications. Journal of Management Studies, 48: 1044-1070.

Shi, W., Zhang, Y., \& Hoskisson, R. 2019. Examination of CEO-CFO social interaction through language style matching: Outcomes for the $\mathrm{CFO}$ and the organization. Academy of Management Journal, 62: 383-414.

Shi, W., Zhang, Y., \& Hoskisson, R. E. 2017b. Ripple effects of CEO awards: Investigating the acquisition activities of superstar CEOs' competitors. Strategic Management Journal, 38: 2080-2102.

Shleifer, A., \& Vishny, R. W. 1988. Value maximization and the acquisition process. Journal of Economic Perspectives, 2: 7-20.

Singh, R. 1998. Takeover bidding with toeholds: The case of the owner's curse. Review of Financial Studies, 11: 679-704.

Sleptsov, A., Anand, J., \& Vasudeva, G. 2013. Relational configurations with information intermediaries: The effect of firm-investment bank ties on expected acquisition performance. Strategic Management Journal, 34: 957-977.

Stuart, T. E., \& Yim, S. 2010. Board interlocks and the propensity to be targeted in private equity transactions. Journal of Financial Economics, 97: 174-189.

Trautwein, F. 1990. Merger motives and merger prescriptions. Strategic Management Journal, 11: 283-295.

Travlos, N. G. 1987. Corporate takeover bids, methods of payment, and bidding firms' stock returns. Journal of Finance, 42: 943-963.

Trichterborn, A., Knyphausen-Aufsess, D. Z., \& Schweizer, L. 2016. How to improve acquisition performance: The role of a dedicated M\&A function, M\&A learning process, and M\&A capability. Strategic Management Journal, 37: 763-773.

Tuggle, C. S., Schnatterly, K., \& Johnson, R. A. 2010. Attention patterns in the boardroom: How board composition and processes affect discussion of entrepreneurial issues. Academy of Management Journal, 53: 550-571.

Turk, T. A. 1992. Takeover resistance, information leakage, and target firm value. Journal of Management, 18: 503-522.

Vaara, E., \& Monin, P. 2010. A recursive perspective on discursive legitimation and organizational action in mergers and acquisitions. Organization Science, 21: 3-22. 
Vaara, E., \& Tienari, J. 2011. On the narrative construction of multinational corporations: An antenarrative analysis of legitimation and resistance in a cross-border merger. Organization Science, 22: 370-390.

Van de Ven, A. H. 1992. Suggestions for studying strategy process: A research note. Strategic Management Journal, 13: 169-188.

Walkling, R. A., \& Long, M. S. 1984. Agency theory, managerial welfare, and takeover bid resistance. Rand Journal of Economics, 15: 54-68.

Walsh, J. P. 1989. Doing a deal: Merger and acquisition negotiations and their impact upon target company top management turnover. Strategic Management Journal, 10: 307-322.

Wan, W. P., \& Yiu, D. W. 2009. From crisis to opportunity: Environmental jolt, corporate acquisitions, and firm performance. Strategic Management Journal, 30: 791-801.

Westbrock, B., Muehlfeld, K., \& Weitzel, U. 2019. Selecting legal advisors in M\&As: Organizational learning and the role of multiplicity of mental models. Journal of Management, 45: 2193-2224.

Wulf, J. 2004. Do CEOs in mergers trade power for premium? Evidence from "mergers of equals". Journal of Law, Economics, and Organization, 20: 60-101.

Xu, D., Zhou, C. H., \& Phan, P. H. 2010. A real options perspective on sequential acquisitions in China. Journal of International Business Studies, 41: 166-174.

Yang, M., \& Hyland, M. 2006. Who do firms imitate? A multilevel approach to examining sources of imitation in the choice of mergers and acquisitions. Journal of Management, 32: 381-399.

Yim, S. 2013. The acquisitiveness of youth: CEO age and acquisition behavior. Journal of Financial Economics, 108: 250-273.

Yu, Y., Umashankar, N., \& Rao, V. R. 2016. Choosing the right target: Relative preferences for resource similarity and complementarity in acquisition choice. Strategic Management Journal, 37: 1808-1825.

Zaheer, A., Hernandez, E., \& Banerjee, S. 2010. Prior alliances with targets and acquisition performance in knowledge-intensive industries. Organization Science, 21: 1072-1091.

Zeng, Y. P., Douglas, T. J., \& Wu, C. Q. 2013. The seller's perspective on determinants of acquisition likelihood: Insights from China's beer Industry. Journal of Management Studies, 50: 673-698.

Zhao, X. 2009. Technological innovation and acquisitions. Management Science, 55: 1170-1183.

Zhu, D. H. 2013. Group polarization on corporate boards: Theory and evidence on board decisions about acquisition premiums. Strategic Management Journal, 34: 800-822.

Zhu, D. H., \& Chen, G. 2015. CEO narcissism and the impact of prior board experience on corporate strategy. Administrative Science Quarterly, 60: 31-65. 
Figure 1: Trends in Research Investigating the Pre-Deal Phase of M\&As Number of Articles by Discipline and by Key Groups of Decisions and Activities
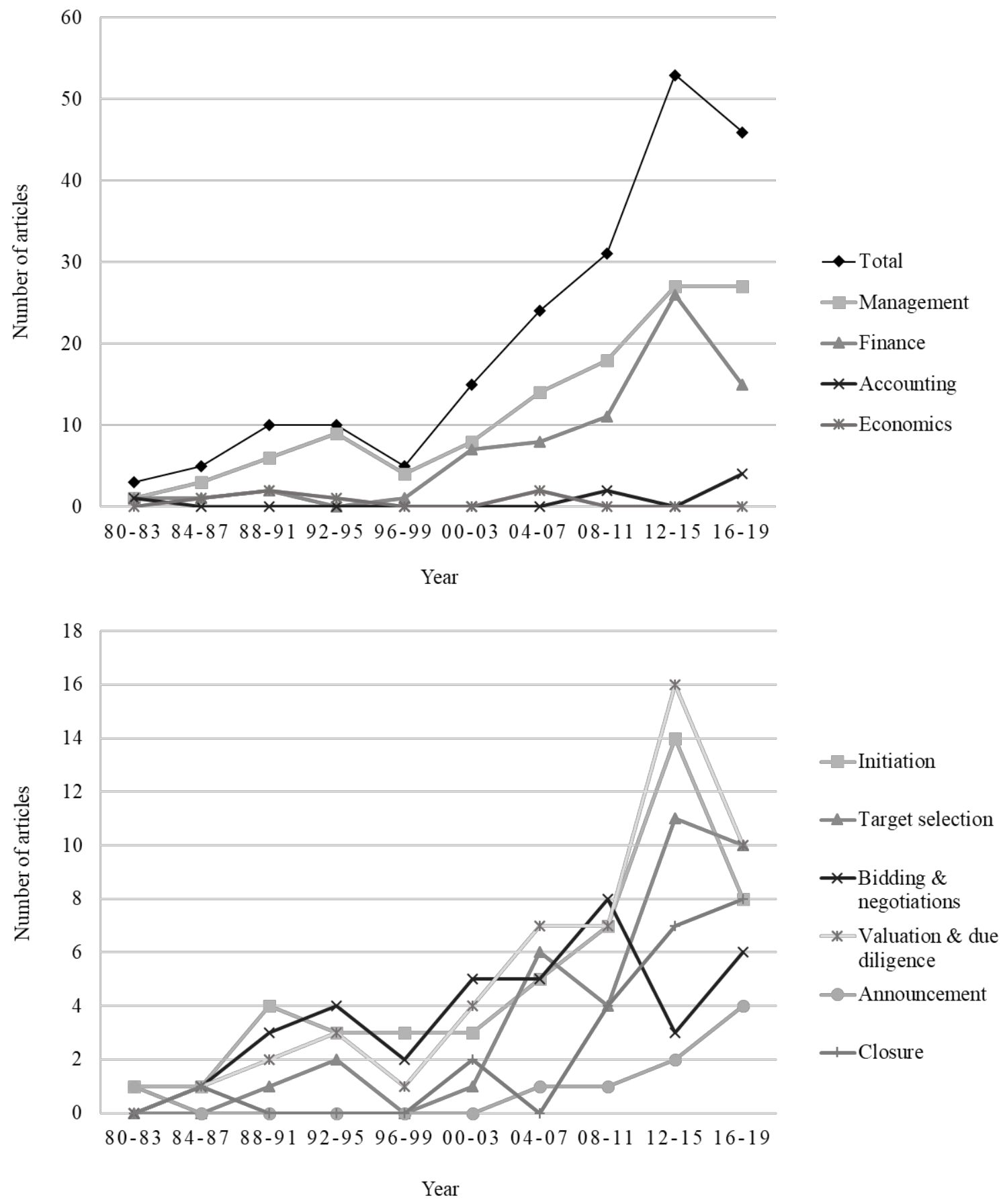
Table 1: Synthesis of Pre-Deal Research and Examples of Research Gaps

\begin{tabular}{|c|c|c|c|c|c|}
\hline & $\begin{array}{l}\text { Themes in } \\
\text { pre-deal research }\end{array}$ & $\begin{array}{l}\text { Theories in pre-deal } \\
\text { research }\end{array}$ & $\begin{array}{l}\text { Examples of gaps: } \\
\text { Coarse-grained } \\
\text { activities and processes }\end{array}$ & $\begin{array}{l}\text { Examples of gaps: } \\
\text { Insufficient } \\
\text { understanding of the } \\
\text { multiple actors and } \\
\text { their interactions }\end{array}$ & $\begin{array}{l}\text { Examples of gaps: } \\
\text { Lack of attention to } \\
\text { temporal dynamics }\end{array}$ \\
\hline $\begin{array}{l}\text { Initiation } \\
\text { Why, how and when } \\
\text { do firms engage in } \\
\text { M\&As? }\end{array}$ & $\begin{array}{l}\text { - M\&A motives } \\
\text { - Imitation } \\
\text { - Social comparisons } \\
\text { - Executive } \\
\text { characteristics } \\
\text { - Ownership and } \\
\text { governance }\end{array}$ & $\begin{array}{l}\text { - Institutional theory } \\
\text { - Behavioral theory } \\
\text { - Agency theory } \\
\text { - Upper echelons theory }\end{array}$ & $\begin{array}{l}\text { - The role of M\&A } \\
\text { strategy } \\
\text { - Counterfactuals - deals } \\
\text { that were internally } \\
\text { analyzed but ultimately } \\
\text { not realized } \\
\text { - Bottom-up versus top- } \\
\text { down initiated M\&As }\end{array}$ & $\begin{array}{l}\text { - Interactions between } \\
\text { owners, directors and } \\
\text { executives } \\
\text { - The role of investment } \\
\text { banks and investment } \\
\text { advisors }\end{array}$ & $\begin{array}{l}\text { - Parallel pre-deal } \\
\text { processes } \\
\text { - Temporal } \\
\text { embeddedness of the } \\
\text { deal making process }\end{array}$ \\
\hline $\begin{array}{l}\text { Target selection } \\
\text { How do firms select } \\
\text { M\&A partners? }\end{array}$ & $\begin{array}{l}\text { - Target attractiveness } \\
\text { - Learning to select } \\
\text { targets } \\
\text { - Information } \\
\text { symmetries } \\
\text { - Contextual influences }\end{array}$ & $\begin{array}{l}\text { - Resource and } \\
\text { capability-based } \\
\text { perspectives } \\
\text { - Information economics } \\
\text { - Organizational } \\
\text { learning } \\
\text { - Relational perspectives } \\
\text { - Institutional theory }\end{array}$ & $\begin{array}{l}\text { - Internal processes of } \\
\text { target mapping and } \\
\text { screening that precede } \\
\text { target selection } \\
\text { - Contextually bounded } \\
\text { target selection } \\
\text { processes }\end{array}$ & $\begin{array}{l}\text { - The role of M\&A } \\
\text { function in target } \\
\text { selection } \\
\text { - The role of executives } \\
\text { and directors in target } \\
\text { selection } \\
\text { - The interactions } \\
\text { between internal and } \\
\text { external actors }\end{array}$ & $\begin{array}{l}\text { - Grooming potential } \\
\text { targets over time } \\
\text { - Recursiveness in the } \\
\text { target selection process } \\
\text { - Windows of } \\
\text { opportunities in target- } \\
\text { initiated deals }\end{array}$ \\
\hline $\begin{array}{l}\text { Bidding and } \\
\text { negotiation } \\
\text { How do firms bid } \\
\text { and bargain over the } \\
\text { terms of M\&A } \\
\text { deals? }\end{array}$ & $\begin{array}{l}\text { - Competition in bidding } \\
\text { - Deal commitment } \\
\text { - Negotiations tactics } \\
\text { - Hostility and trust }\end{array}$ & $\begin{array}{l}\text { - Information economics } \\
\text { - Decision making } \\
\text { theory } \\
\text { - Status theory } \\
\text { - Trust-based } \\
\text { perspectives }\end{array}$ & $\begin{array}{l}\text { - Characteristics of due } \\
\text { diligence } \\
\text { - Negotiations and PMI } \\
\text { - Parallel negotiations in } \\
\text { M\&A programs } \\
\text { - M\&A tools and } \\
\text { practices }\end{array}$ & $\begin{array}{l}\text { - Characteristics of due } \\
\text { diligence teams } \\
\text { - Acquirer and target } \\
\text { negotiation teams and } \\
\text { their interactions } \\
\text { - Decision making of } \\
\text { advisors }\end{array}$ & $\begin{array}{l}\text { - Timing of initial bid } \\
\text { and bid revisions } \\
\text { - Negotiations length } \\
\text { and rhythm } \\
\text { - Due diligence and } \\
\text { negotiation interruptions }\end{array}$ \\
\hline
\end{tabular}




\begin{tabular}{|c|c|c|c|c|c|}
\hline $\begin{array}{l}\text { Valuation, } \\
\text { financial terms and } \\
\text { financing } \\
\text { How do firms } \\
\text { decide on the } \\
\text { acquired stake, deal } \\
\text { price, method of } \\
\text { payment, and source } \\
\text { of deal financing? }\end{array}$ & $\begin{array}{l}\text { - Valuation process } \\
\text { - Antecedents to the } \\
\text { M\&A premium } \\
\text { - Biases in M\&A } \\
\text { premium setting } \\
\text { - Acquired stake } \\
\text { - Method of payment } \\
\text { - Deal financing }\end{array}$ & $\begin{array}{l}\text { - Information economics } \\
\text { - Decision making } \\
\text { theory } \\
\text { - Agency theory } \\
\text { - Institutional theory } \\
\text { - Upper echelon theory } \\
\text { - Human capital theory }\end{array}$ & $\begin{array}{l}\text { - Pre-deal } \\
\text { considerations: breakup } \\
\text { fees, lock-up, and } \\
\text { exclusivity } \\
\text { - Antecedents to the } \\
\text { acquired stake and } \\
\text { method of payment } \\
\text { - Tradeoffs in terms of } \\
\text { M\&A deals }\end{array}$ & $\begin{array}{l}\text { - The role of the boards } \\
\text { and advisors in } \\
\text { debiasing premium } \\
\text { decisions } \\
\text { - The impact of acquirer } \\
\text { and target shareholders } \\
\text { - Decision biases of } \\
\text { advisors }\end{array}$ & $\begin{array}{l}\text { - Recursions in } \\
\text { bargaining, valuation } \\
\text { and due diligence } \\
\text { - Emergence of the deal } \\
\text { terms over time } \\
\text { - Timing of deal } \\
\text { financing decisions }\end{array}$ \\
\hline $\begin{array}{l}\text { Announcement } \\
\text { When and how do } \\
\text { firms announce } \\
\text { M\&As? }\end{array}$ & $\begin{array}{l}\text { - Impression } \\
\text { management } \\
\text { - Information leakage }\end{array}$ & $\begin{array}{l}\text { - Socio-cognitive } \\
\text { theories related to } \\
\text { market appraisal }\end{array}$ & $\begin{array}{l}\text { - The interplay between } \\
\text { announcement and } \\
\text { completion } \\
\text { - Managing shareholder } \\
\text { reactions } \\
\text { - Long-term effects of } \\
\text { impression management }\end{array}$ & $\begin{array}{l}\text { - Individual actors who } \\
\text { decide on the use of } \\
\text { impression management } \\
\text { - Impression } \\
\text { management by actors } \\
\text { in target firms } \\
\text { - The "inner circle" and } \\
\text { information leakages }\end{array}$ & $\begin{array}{l}\text { - Timing of information } \\
\text { leakages } \\
\text { - Timing of M\&A } \\
\text { announcement } \\
\text { - Timing of M\&A } \\
\text { conference calls } \\
\text { - Temporal features of } \\
\text { impression management } \\
\text { tactics }\end{array}$ \\
\hline $\begin{array}{l}\text { Closure } \\
\text { Whether to close or } \\
\text { withdraw from a } \\
\text { publicly announced } \\
\text { M\&A? }\end{array}$ & $\begin{array}{l}\text { - Reducing deal } \\
\text { uncertainty } \\
\text { - Contracting } \\
\text { - Factors that facilitate / } \\
\text { hinder deal closure } \\
\text { (internal and external) } \\
\text { - Length of public } \\
\text { takeover process }\end{array}$ & $\begin{array}{l}\text { - Information economics } \\
\text { - Institutional theory } \\
\text { - Agency theory } \\
\text { - Learning theory }\end{array}$ & $\begin{array}{l}\text { - Workload associated } \\
\text { with regulatory } \\
\text { compliance } \\
\text { - Integration planning } \\
\text { activities } \\
\text { - Interplay of integration } \\
\text { planning and execution }\end{array}$ & $\begin{array}{l}\text { - The role of } \\
\text { competition authorities } \\
\text { - Responsibilities for } \\
\text { integration planning and } \\
\text { execution } \\
\text { - Interactions between } \\
\text { negotiation teams and } \\
\text { integration teams }\end{array}$ & $\begin{array}{l}\text { - Psychological } \\
\text { phenomena that } \\
\text { manifest over time: } \\
\text { escalation of } \\
\text { commitment and } \\
\text { bandwagons } \\
\text { - Length of competition } \\
\text { authority assessment } \\
\text { - Early decisions and } \\
\text { deal closure }\end{array}$ \\
\hline
\end{tabular}




\section{Online Supplement}

Table A1: Counts of Articles across Disciplines, Journals and Key Activities in the Pre-deal Phase of M\&A

\begin{tabular}{|c|c|c|c|c|c|c|c|}
\hline & Initiation & $\begin{array}{l}\text { Target } \\
\text { selection }\end{array}$ & $\begin{array}{l}\text { Bidding and } \\
\text { negotiation }\end{array}$ & $\begin{array}{l}\text { Valuation, } \\
\text { financial terms } \\
\text { and financing }\end{array}$ & Announcement & Closure & Total \\
\hline Accounting & 1 & 2 & 1 & 2 & 1 & 0 & 7 \\
\hline AR & 0 & 0 & 0 & 0 & 1 & 0 & 1 \\
\hline JAE & 0 & 2 & 1 & 2 & 0 & 0 & 5 \\
\hline JAR & 1 & 0 & 0 & 0 & 0 & 0 & 1 \\
\hline Economics & 1 & 0 & 2 & 2 & 0 & 1 & 6 \\
\hline AER & 0 & 0 & 0 & 1 & 0 & 0 & 1 \\
\hline JEP & 0 & 0 & 0 & 1 & 0 & 0 & 1 \\
\hline RJE & 1 & 0 & 2 & 0 & 0 & 1 & 4 \\
\hline Finance & 10 & 9 & 17 & 25 & 4 & 7 & 72 \\
\hline JOF & 3 & 3 & 5 & 7 & 3 & 1 & 22 \\
\hline JFE & 6 & 4 & 8 & 11 & 1 & 5 & 35 \\
\hline RFS & 1 & 1 & 1 & 6 & 0 & 0 & 9 \\
\hline JFQA & 0 & 1 & 3 & 1 & 0 & 1 & 6 \\
\hline Management & 36 & 23 & 18 & 22 & 4 & 14 & 117 \\
\hline AMJ & 7 & 0 & 3 & 2 & 2 & 0 & 14 \\
\hline AMR & 0 & 1 & 3 & 2 & 0 & 0 & 6 \\
\hline ASQ & 6 & 3 & 1 & 4 & 0 & 0 & 14 \\
\hline JIBS & 1 & 2 & 1 & 4 & 0 & 2 & 10 \\
\hline JMS & 1 & 2 & 2 & 0 & 1 & 1 & 7 \\
\hline JOM & 3 & 2 & 1 & 2 & 0 & 3 & 11 \\
\hline MS & 2 & 1 & 0 & 2 & 0 & 4 & 9 \\
\hline OS & 0 & 2 & 4 & 1 & 0 & 0 & 7 \\
\hline SMJ & 16 & 10 & 3 & 5 & 1 & 4 & 39 \\
\hline Total & 48 & 34 & 38 & 51 & 9 & 22 & 202 \\
\hline
\end{tabular}

Note: Articles that examine more than one stage of the pre-deal process were counted only once. AR = Accounting Review; JAE $=$ Journal of Accounting Economics; JAR $=$ Journal of Accounting Research; AER = American Economic Review; JEP = Journal of Economic Perspectives; RJE = Rand Journal of Economics; JOF = Journal of Finance; JFE = Journal of Financial Economics; RFS = Review of Financial Studies; JFQA = Journal of Financial and Quantitative Analysis; AMJ = Academy of Management Journal; AMR = Academy of Management Review; ASQ = Administrative Science Quarterly; JIBS = Journal of International Business Studies; JMS = Journal of Management Studies; JOM = Journal of Management; MS = Management Science; OS = Organization Science; SMJ = Strategic Management Journal; 
Table A2: Questions for Future Research

\begin{tabular}{|c|c|c|c|}
\hline & $\begin{array}{l}\text { Research theme 1: From aggregate } \\
\text { decisions to granular processes }\end{array}$ & $\begin{array}{l}\text { Research theme 2: From individual } \\
\text { actors to multiple actors and their } \\
\text { interactions }\end{array}$ & $\begin{array}{l}\text { Research theme 3: From static to } \\
\text { dynamic perspectives }\end{array}$ \\
\hline Initiation & $\begin{array}{l}\text { What is the role of M\&A strategy in firm } \\
\text { decision-making regarding M\&A initiation? } \\
\text { How and what do companies learn from } \\
\text { unrealized M\&As? } \\
\text { How does the pre-deal process and outcomes } \\
\text { differ in bottom-up versus top down initiated } \\
\text { deals? }\end{array}$ & $\begin{array}{l}\text { How do the interactions between executives, } \\
\text { directors and owners affect M\&A initiation? } \\
\text { What is the role of investment banks and } \\
\text { investment advisors in M\&A initiation? } \\
\text { How do championing, issue selling, and the } \\
\text { build-up of coalitions among divisional } \\
\text { management, M\&A specialists, the TMT } \\
\text { and the board affect M\&A initiation? }\end{array}$ & $\begin{array}{l}\text { How does the timing of different parallel } \\
\text { strategic initiatives affect M\&A initiation? } \\
\text { How long are the internal discussions about } \\
\text { a potential deal before the official initiation } \\
\text { decision has been made? } \\
\text { Under what conditions do frequent acquirers } \\
\text { abstain from initiating M\&As for a long } \\
\text { period of time? }\end{array}$ \\
\hline $\begin{array}{l}\text { Target } \\
\text { selection }\end{array}$ & $\begin{array}{l}\text { How do companies internally organize target } \\
\text { mapping and screening processes? } \\
\text { How do different target mapping and } \\
\text { screening processes affect target selection } \\
\text { decisions? } \\
\text { What is the role of the M\&A department in } \\
\text { the target selection process? }\end{array}$ & $\begin{array}{l}\text { In what capacity and when do members of } \\
\text { TMTs or divisional managers become } \\
\text { involved in the pre-deal process? } \\
\text { How do interactions between internal } \\
\text { players (e.g., executives, directors) and } \\
\text { external players (e.g., consultants and } \\
\text { advisors) affect target selection? } \\
\text { How do investment banks and advisors } \\
\text { scout for M\&A targets? }\end{array}$ & $\begin{array}{l}\text { How do firms that anticipate the purchase or } \\
\text { sale of a firm prepare for deal making } \\
\text { activities over time? } \\
\text { How do acquirers groom potential targets } \\
\text { over time for an acquisition? } \\
\text { How does the turnover in the upper echelons } \\
\text { affect ongoing mapping and screening } \\
\text { processes over time? }\end{array}$ \\
\hline $\begin{array}{l}\text { Bidding and } \\
\text { negotiation }\end{array}$ & $\begin{array}{l}\text { How does the comprehensiveness of the due } \\
\text { diligence affect subsequent stages of the } \\
\text { M\&A process and outcomes? } \\
\text { To what extent is PMI a topic of deal } \\
\text { negotiations and what implications this has } \\
\text { on PMI outcomes? } \\
\text { How do companies organize and } \\
\text { synchronize M\&A processes in parallel deal } \\
\text { negotiations? }\end{array}$ & $\begin{array}{l}\text { Who constitutes the negotiation teams in the } \\
\text { merging firm, and how do the characteristics } \\
\text { of these teams affect the pre-deal process } \\
\text { and outcomes? } \\
\text { To whom and when do the boards of } \\
\text { merging firms delegate authority to lead the } \\
\text { pre-deal process? } \\
\text { Do M\&A teams develop heuristics for } \\
\text { assessing targets and negotiating deals? }\end{array}$ & $\begin{array}{l}\text { How does the timing of initial formal bid } \\
\text { and bid revisions affect pre-deal process and } \\
\text { outcomes? } \\
\text { How does the speed of due diligence affect } \\
\text { acquirers' bargaining power in M\&A } \\
\text { negotiations? } \\
\text { What are the implications of deliberate } \\
\text { delays by targets during the negotiation } \\
\text { process on deal outcomes? }\end{array}$ \\
\hline
\end{tabular}




\begin{tabular}{|c|c|c|c|}
\hline $\begin{array}{l}\text { Valuation, } \\
\text { financial terms } \\
\text { and financing }\end{array}$ & $\begin{array}{l}\text { What are the decision-making processes } \\
\text { behind various deal considerations such as } \\
\text { exclusivity agreements, lock-ups or breakup } \\
\text { fees? } \\
\text { How do firms adjust their decisions } \\
\text { regarding the acquired stake and method of } \\
\text { payment? } \\
\text { What tradeoffs do companies make } \\
\text { regarding the terms of M\&A deals, and } \\
\text { under what conditions? }\end{array}$ & $\begin{array}{l}\text { How do acquirer and target shareholders } \\
\text { influence the valuation process and financial } \\
\text { terms of a deal? } \\
\text { What is the role of advisors in preventing or } \\
\text { mitigating biases of executives and directors } \\
\text { that go into M\&A premium decisions? } \\
\text { What biases do external players such as } \\
\text { advisors introduce in the valuation process } \\
\text { and how? }\end{array}$ & $\begin{array}{l}\text { How does time pressure affect deal } \\
\text { valuation? } \\
\text { When and how does new information that } \\
\text { surfaces during due diligence lead to } \\
\text { adjustments in the assumptions that underlie } \\
\text { the acquirer's and target's valuation? } \\
\text { How does the timing of decisions regarding } \\
\text { deal financing affect deal outcomes? }\end{array}$ \\
\hline Announcement & $\begin{array}{l}\text { How do firms manage the reactions to M\&A } \\
\text { announcements of various internal and } \\
\text { external stakeholders? } \\
\text { Does the termination of already announced } \\
\text { deals have repercussions for potential } \\
\text { targets? } \\
\text { What are the long-term effects of the } \\
\text { impression management approaches often } \\
\text { used by firms during M\&A announcements? }\end{array}$ & $\begin{array}{l}\text { Which individuals shape decisions } \\
\text { regarding the use of impression } \\
\text { management and how? } \\
\text { What impression management tactics are } \\
\text { used by actors in target firms? } \\
\text { How are the choices made during the pre- } \\
\text { deal phase regarding the size of the inner } \\
\text { circle related to the likelihood of rumors? }\end{array}$ & $\begin{array}{l}\text { How does the timing of information leakage } \\
\text { about a potential deal affect the pre-deal } \\
\text { process and outcomes? } \\
\text { How and to what extent (if at all) do public } \\
\text { reactions following the announcement } \\
\text { trigger the reassessment of the initial plans } \\
\text { or even the re-negotiation of the deal terms? } \\
\text { How do companies decide on the timing of } \\
\text { an M\&A announcement? }\end{array}$ \\
\hline Closure & $\begin{array}{l}\text { What is the workload for the acquirer and } \\
\text { the target associated with the regulatory } \\
\text { compliance of a deal? } \\
\text { What, if any, is the relationship between } \\
\text { M\&A integration planning and deal closure? } \\
\text { To what extent is the deal making process in } \\
\text { the closure stage internally versus externally } \\
\text { driven? }\end{array}$ & $\begin{array}{l}\text { Do the competition authorities influence the } \\
\text { duration of the public takeover stage, and } \\
\text { what is the likelihood of deal closure? } \\
\text { What are the consequences of withdrawal } \\
\text { from an announced deal for executives and } \\
\text { directors in acquiring and target firms? } \\
\text { Do negotiation teams and integration teams } \\
\text { interact as the deal proceeds to closure, and } \\
\text { how do these interactions affect PMI? }\end{array}$ & $\begin{array}{l}\text { How does the length and timing of } \\
\text { competition authority assessment affect deal } \\
\text { closure? } \\
\text { How do psychological phenomena such as } \\
\text { escalation of commitment manifest over } \\
\text { time and influence deal closure? } \\
\text { Are the effects of early M\&A decisions path- } \\
\text { dependent, and how do they affect deal } \\
\text { closure? }\end{array}$ \\
\hline
\end{tabular}

